\title{
Agriculture as spectacle
}

\author{
Glenn Davis Stone ${ }^{1}$ \\ Washington University in St. Louis, USA
}

\begin{abstract}
In the influential "performance" model of agriculture, the appearance of the farm is the unintentional result of improvisational decision-making rather than the intentional result of design. However in many ways agriculture is explicitly intended to produce an appearance, often aimed at a specific audience. This phenomenon, termed agricultural spectacle, comes in many forms and serves varied aims. This article offers a theoretical framework beginning with a consideration of how agricultural spectacle differs from other classes of spectacle and from generalized societal spectacle as theorized by Debord. Most important in this regard is that agricultural spectacle generally functions as a form of synecdoche as it presents a temporal or spatial part as a representation of the whole agricultural operation. It also often relies on "captioning" to render ambiguous sights striking to viewers. But agricultural spectacle is highly diverse, as shown by exploring three axes of variation. The first axis concerns the extent to which agricultural activities are adjusted for their impact on viewers, as opposed to being conducted purely for utility and rendered spectacular after the fact. The second compares the intent of the agricultural spectacle. The last axis distinguishes scale, from plant part to field to farm to landscape.
\end{abstract}

Key Words: agriculture, spectacle, indigenous knowledge, propaganda, performance

\section{Résumé}

Dans le modèle influent de «performance» de l'agriculture, l'apparence de la ferme est le résultat involontaire de la prise de décision en matière d'improvisation plutôt que le résultat intentionnel de la conception. Cependant, à bien des égards, l'agriculture vise explicitement à produire une apparence, souvent destinée à un public spécifique. Ce phénomène, appelé «spectacle agricole», prend de nombreuses formes et sert des objectifs variés. Cet article propose un cadre théorique commençant par une réflexion sur la différence entre le spectacle agricole et les autres classes de spectacle et sur le spectacle sociétal généralisé tel que théorisé par Debord. Le plus important à cet égard est que le spectacle agricole fonctionne généralement comme une forme de synecdoche car il présente une partie temporelle ou spatiale en tant que représentation de l'ensemble de l'exploitation agricole. Il repose également souvent sur le «sous-titrage» pour rendre les vues ambiguës frappantes pour les téléspectateurs. Mais le spectacle agricole est très diversifié, car l'exploration de trois axes de variation sera révélée. Le premier axe concerne la mesure dans laquelle les activités agricoles sont ajustées en fonction de leur impact sur les téléspectateurs, au lieu d'être menées uniquement pour des raisons d'utilité et rendues spectaculaires après l'événement. La seconde compare l'intention du spectacle agricole. Le dernier axe distingue l'échelle, d'une partie d'une plante à un champ, à une ferme et à un paysage.

Mots-clés: agriculture, spectacle, savoir autochtone, propagande, performance

\section{Resumen}

En el influyente modelo del "performance" de agricultura, la apariencia de la granja es el resultado involuntario de la improvisada toma de decisiones, más que el resultado intencional del diseño. Sin embargo, la agricultura es, en muchos sentidos, explícitamente planeada para producir una apariencia normalmente dirigida a una audiencia particular. Este fenómeno, denominado espectáculo agrícola, se presenta de diversas formas y tiene varios objetivos. Este artículo ofrece un marco teórico que comienza considerando cómo el

\footnotetext{
${ }^{1}$ Dr. Glenn Davis Stone, Professor of Anthropology and Environmental Studies, Washington University, St. Louis MO 63130, USA. Email: stone "at" wustl.edu. For discussion I am grateful to Pascal Boyer, Mark Rollins, Fred Hebard, Simon Batterbury, Andrew Flachs, and Jim Igoe. Special thanks to Carole Slatkin. Thanks to Andrew Flachs for organizing the Heidelberg workshop and to Paul Richards for his nonstop flow of interesting ideas. This is the third article in Andrew Flachs (ed.). 2018. "Performing development roles: theorizing agriculture as performance", Special Section of the Journal of Political Ecology 25: 638-764.
} 
espectáculo agrícola difiere de otros tipos de espectáculo, así como de espectáculos sociales generalizados, tal como Debord teoriza. Aún más importante en este sentido, es que el espectáculo agrícola funciona normalmente como una forma de sinécdoque, al presentar una parte temporal o espacial como una representación de la operación agrícola completa. Frecuentemente también depende de un "subtitulado" que traduce impresiones ambiguas que resultan impactantes para los espectadores. Pero el espectáculo agrícola es muy diverso, como se demuestra al explorar tres ejes de variación. El primer eje refiere que tanto las actividades agrícolas se ajustan para su impacto en los espectadores, contrario a cuando están dirigidas únicamente por su utilidad y representada espectacularmente luego del hecho. El segundo eje compara la intención del espectáculo agrícola. El último eje distingue la escala, desde la parte de la planta al campo, a la granja y al paisaje.

Palabras clave: agricultura, espectáculo, conocimiento nativo, propaganda, performance

\section{Introduction}

In a famous pair of essays, Paul Richards sees the practice of agriculture as a performance (1993, 1989). From this perspective agricultural decision-making is driven less by the application of an indigenous "knowledge system" than by "a set of improvisational capacities called forth by the needs of the moment" (Richards, 1993: 62). Thus what we see in the fields of Hausa farmers (Watts 1983) is less the result of any pre-determined design than of a series of extemporaneous actions, both social and agronomic, comprising a "completed performance" (Richards 1989). The comparison is to musicians on stage.

Like many social scientists concerned with agriculture, I cite this invaluable perspective frequently. But it does simplify a bit. The fact that farmers improvise does not mean they operate without indigenousknowledge-based plans and models; there must be a dialectic between planning and improvisation, and the relative contribution of the two forms of decision-making likely varies with the local agricultural environment (Batterbury 1996: 14).

Furthermore, unlike the musicians in his metaphor, Richards' farmers perform to no audience. The only audience seems to be the implied indigenous-knowledge-fetishizing spectators - but these are the very ones who get it wrong, and it is they who are invited to disregard the appearance of the farm. The farmers are certainly not performing for any such spectators.

And yet agriculture takes place out in the open — in the $\boldsymbol{a g r i}^{2}$ — where it is always on view. Farms transmit information to the local community about the farmer's character, status and wealth, as Batterbury (1996: 17-18) pointed out, but this is only the beginning. Many aspects of agricultural enterprise are explicitly intended to be viewed by an audience, are adjusted for an audience, and may even be created for an audience. Agriculture is, or can be made into, a spectacle (a concept to be unpacked shortly), deployed in pursuit of political, social or economic ends. Agricultural spectacle can be created at a wide range of scales. Benito Mussolini created an enormous spectacle when he drained the Pontine Marshes south of Rome in the mid1930s to construct an idealized fascist agricultural landscape (Caprotti and Kaïka 2008). As part of Italy's "Battle for Wheat" after the League of Nations imposed import sanctions, the precise wheat fields and planned towns served as a form of landesque propaganda capital for newsreels and posters. Benito Mussolini himself appears in one newsreel, bare-chested and sporting rakish goggles as he threshed wheat alongside local farmers (Figure 1) - giving new meaning to the notion of agricultural performance.

At the small end of the continuum we can recall the tradition of growing ears of corn for Corn Show competitions (Figure 2). These events thrived in the early 20th century midwestern US and they involved much more than local color at the county fair. Corn shows made a spectacle of the individual cob; and the show itself, with its table after table of yellow ears and black-suited kvelling growers, was a spectacle that could draw substantial crowds. "Big Corn Show Will Bring a Big Crowd Here", headlined the Dassel (Minnesota) Dispatch in January 1921.

\footnotetext{
${ }^{2}$ Latin for field.
} 


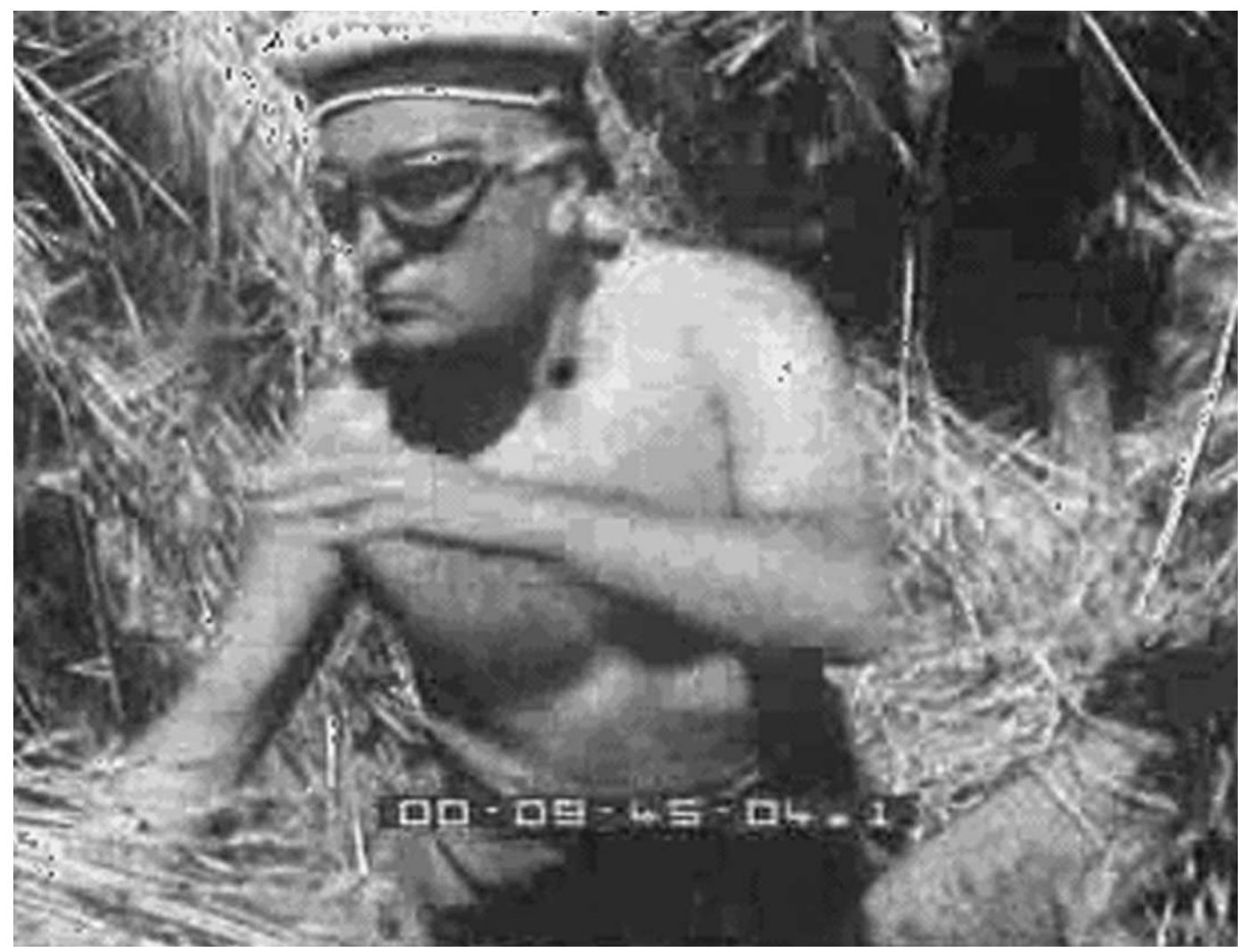

Figure 1: Benito Mussolini performs agriculture for the cameras. Source: Caprotti and Kaïka (2008).
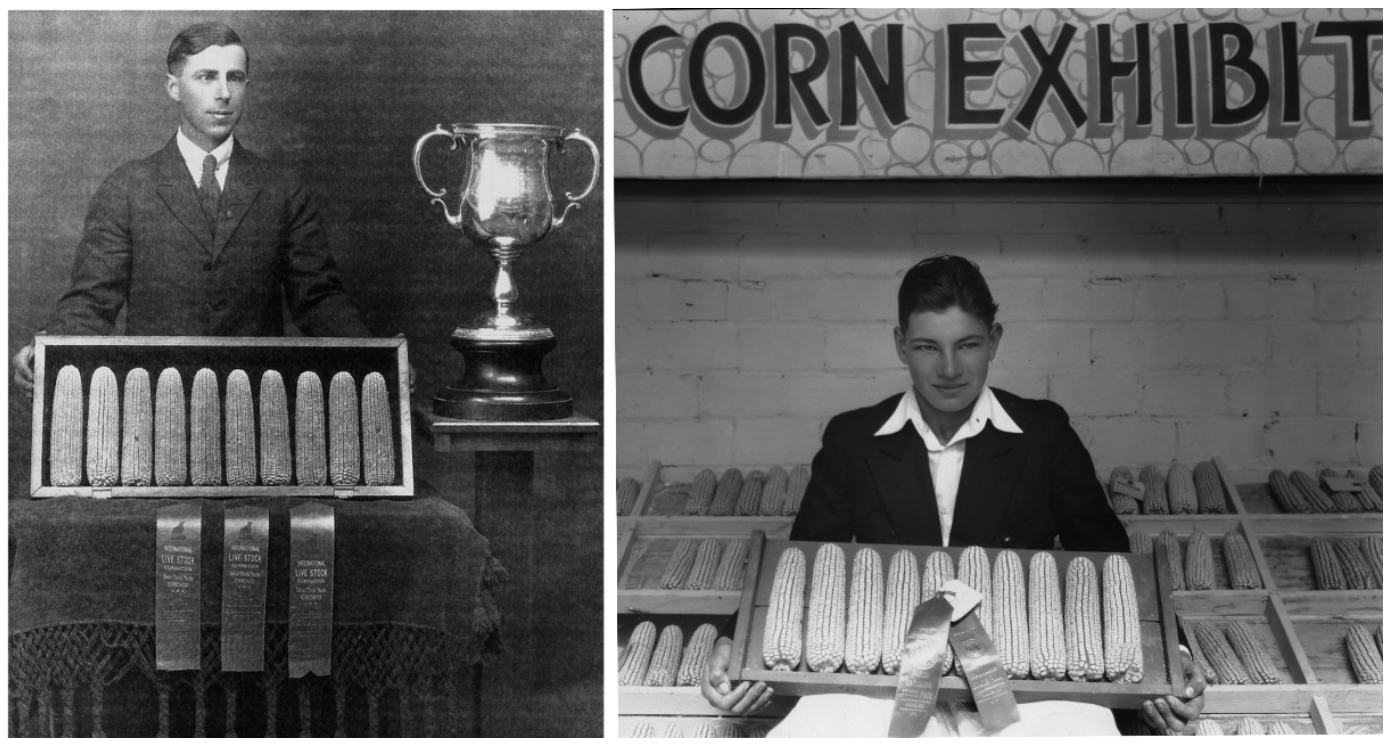

Figure 2: Corn show champions. Source: left Troyer and Palmer (2006), right North Carolina State University. 
Of course it is easy to smirk at Dassel's big crowds as a sure sign of a time when people were very easily entertained, but Iowa Farmer Today's "Corn Cam" (Figure 3) got hundreds of thousand views and developed an international audience with avid fans from England to China, to watch a live feed of - that's right — corn growing in a field (NPR 2001).

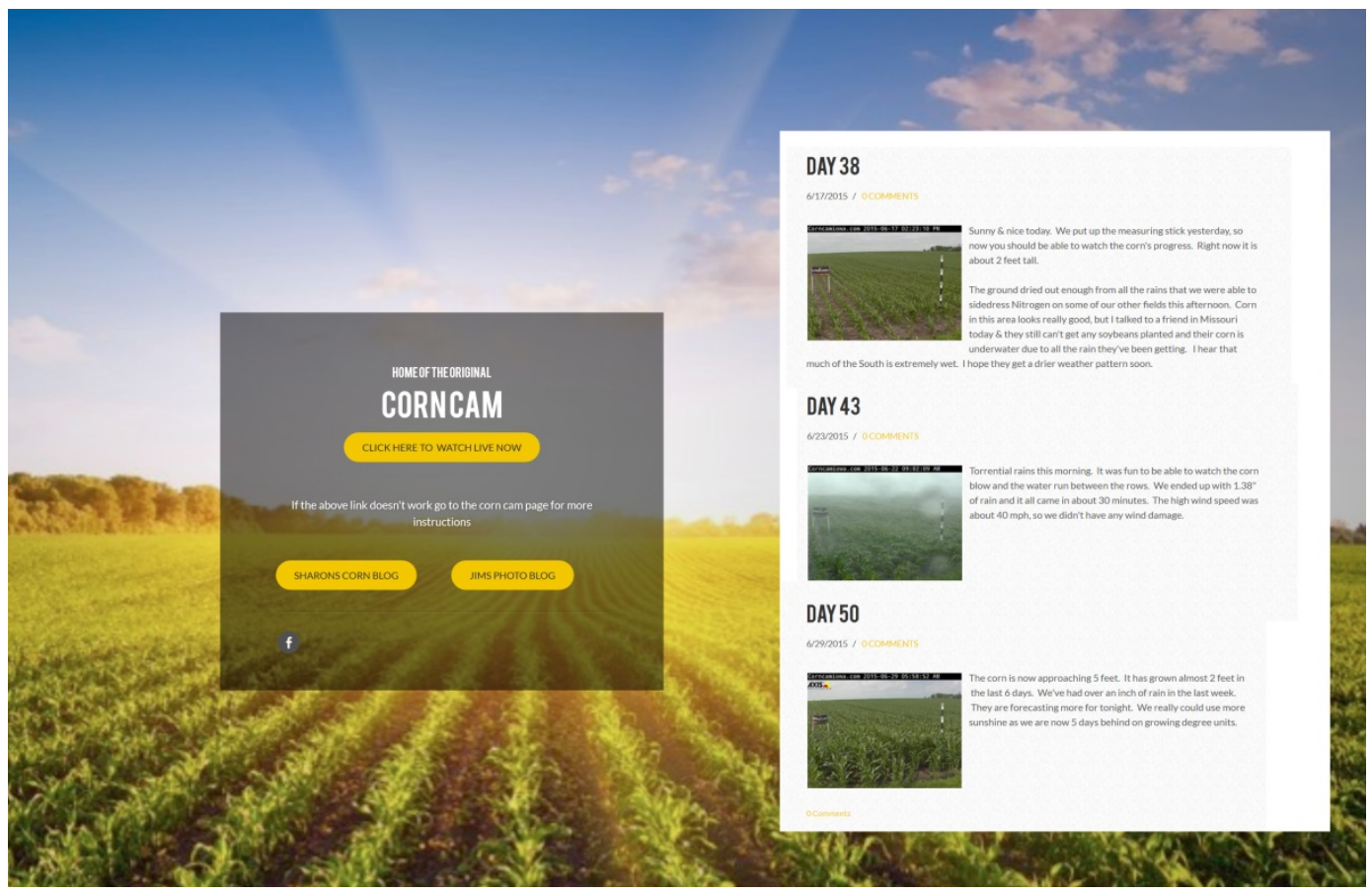

Figure 3: The Corn Cam was located at http://www.corncamiowa.com.

And lest the Pontine Marshes, Corn Shows and Corn Cam seem to be epiphenomenal sideshows that have little to do with the actual work of farming, I would point out that as I write this I am just across the mountains from the endlessly touted and documentarized Polyface Farm near Staunton VA, the mascot for the North American alternative agriculture (or Neo-agrarian) movement. Polyface is open to visitors who can witness animal rearing practices turned into a spectacle that authenticates and advertises the qualities, both tangible and intangible, built into the price of the farm's products.

The Green Revolution itself was a spectacle and owes much of its success to being spectacularized at scales small and large. Mexican farmers clamored for dwarf wheat after seeing rigged demonstration fields (described below), and in Viet Nam the Green Revolution rice "partitioned the landscape, drawing a boundary between traditional and modern agriculture clear enough to be seen through the chin-bubbles of helicopter gunships" (Cullather 2010: 159).

Let us not only relax Richards' simplifying assumption but turn the question around: what can we learn about agriculture by an explicit focus on the actions driven by the visual appearance of agricultural activities - by the creation of agricultural spectacle?

Spectacle is a potent concept with the power to cast its shadow on almost any human endeavor. French theorist Guy Debord famously (at least in radical circles) theorized the levels of spectacle as:

a) concentrated and discrete,

b) diffuse and undelineated, and finally

c) integrated into everything around us (Debord 1967, 1988). 
This is a broad view of spectacle but in one sense my aim is even broader. Debord was a Sun Tzuquoting activist at war with spectacle, which he saw as "capital accumulated to the point that it becomes image" (Debord 1967: Thesis 34); he railed against spectacle as a pervasive instrument of the autocratic reign of the 20th century market economy, and "the totality of new techniques of government that accompanied this reign" (Debord 1988). ${ }^{3}$ Agricultural spectacle is certainly deployed by capital as a tool of accumulation, and by states as a tool of governmentality (Igoe 2013: 38), but it is also used by a diverse range of actors for a wider set of purposes. NGOs create spectacles to showcase their interventions for funders and visitors; entrepreneurial Neo-agrarians turn their farms into spectacles for customers to visit; even conventional farmers cut, mow, fence and fix with community members qua spectators in mind. There is much more to agricultural spectacle than the machinations of capital.

At the same time my aim is narrower than Debord's as I am specifically concerned with spectacle in agriculture. As we narrow our view from generalized spectacle as theorized by Debord (1967) and Manning (1992), we find that particular categories of spectacle embody particular qualities and often perform distinctive functions. Urban spectacle, for instance, is characterized by an essential quality of sensory overload (Addo 2009: 229); human disaster spectacle (such as that brought by Hurricane Katrina) is particularly prone to divergent "decodings and meanings" (Gotham 2007). Igoe (2013) probes the role of spectacle in commodifying nature and finds a history of segregating countrysides into landscapes of production and landscapes of leisure/contemplation. What are the salient features of spectacle in agriculture?

My interest is not in theorizing an abstract construct of spectacle, but in cultivating the concept as a tool for understanding these concrete constructions of agriculture and its performance. I will first consider the characteristics of agriculture that give rise to particular types and uses of spectacle; this requires a dive into the underlying meanings of spectacle and the ways in which spectacular quality is inherent or created by "captioning." But to better understand what spectacle actually does in the context of farming (the question underscored by Tomlinson (2002)) I examine the key set of part-whole relationships. I then explore the three fundamental axes of variability in agricultural spectacle: show (whether agriculture is performed for spectacle or strictly for utility), intent (the aims for which spectacle is created and/or deployed), and scale.

\section{The distinctive nature of spectacle in agriculture}

Agriculture is rare among activities in its high level of uncertainty. At its most uncertain are cases like Indian cotton cultivation, with its chaotic interaction among pest species and agricultural technologies (Stone 2007), but even the highly industrialized and purportedly nature-controlling agriculture of the US has its booms and busts, and most US farmers would be in dire straits without state safety nets. If farmers face a range of uncertainties in running their operations, those who want to judge their operations and their products face their own set of uncertainties. When making decisions in the face of uncertainty, humans are highly dependent on heuristic shortcuts. The essence of heuristics, write Tversky and Kahneman (1974: 1124), is that they facilitate complex tasks of assessment and prediction by substituting "simpler judgmental operations." Tversky and Kahneman's account of decision-making is highly general and has been applied to a wide range of activities, but we find that in agriculture, it is often specifically visual representations that serve as heuristics.

One obvious reason for the centrality of visual heuristics is that agriculture is normally a highly visible transformation of the landscape. Every farm is, in a sense, an installation; every test plot has the potential to wow as well as to provide data; any bull or ear of corn may win a prize for its appearance. A farm field will be regularly observed by neighbors and passers-by, and it may draw visitors and even reporters if it has a special story or appearance. It may be depicted in NGO offices and brochures, documentaries, corporate media, and agricultural extension displays. But this only scratches the surface of what can be accomplished (or attempted) through the visual rhetoric of agriculture. Agriculture per se is too omnibus a construct to be visible, but its various components and practices can strike viewers in ways that further a wide range of

\footnotetext{
${ }^{3}$ For more in-depth engagement with Debord's analysis of spectacle see Tomlinson (2002) and Igoe (2017).
} 
economic, political, social, and environmental projects. But what distinguishes a commonplace farm snapshot from an open-field heuristic that can further such projects?

Consider that etymologically, spectacle derives from the Latin spectare, meaning to watch or gaze at, the frequentative form of specere, meaning to look at. The same root gave the Romans spectaculum as a name for the stands for watching gladiators, and it would later give English speakers both meanings of spectacles along with spectators, inspection, and so on. It also gave us the verb to spectate although this word is rarely used, generally yielding to the verb to watch. The Latin spectare refers to a more active process than to videre, which is the relatively passive act of seeing; the fact that some agency is involved by the viewer implies that the something is worth watching, hence the English adjective spectacular.

Noun and adjective forms of a root may take on different connotations and this has happened here. Spectacular has long since outgrown its original visual reference and is now applied to almost any quality or outcome that is extraordinarily good: a company's quarterly earnings or the results of a biological experiment may be "spectacular" even if they aren't much to look at. But the noun spectacle remains ever visual: those spectacular quarterly earnings were not actually "a spectacle" unless they were announced with fireworks, nor was the experiment unless it turned the test tubes into bright colors. So spectacle refers to phenomena that are "visually striking" or worth going out of one's way to spectate. In Debord's terms, it renders visible a world that is not directly perceivable by the senses (Debord 1967: Thesis 18).

This definition is fairly straightforward but it raises a philosophical question: what makes a phenomenon spectacular? Can we generalize about what properties render a sight "striking"? Are certain sights inherently spectacular, or is specutacule a function of the observer's spectacles? This is a derivative of a classic philosophical problem that been chewed over for centuries by, among others, George "esse is percipi" Berkeley and Zen koans about falling trees: do properties that we perceive exist outside of our perceiving them? Specifically, are certain types of agricultural displays inherently attention-grabbing, senses-pleasing, compelling?

Scholars of art and math have a long tradition of seeking forms, shapes and colors that are inherently pleasing, including sublime triangles, golden ratios, or divine proportions (Huntley 1970). Goethe wrote on the emotional impact of colors (1840 [1810]). These writings have focused largely on small-scale images that we might view on the page or in the frame. Agricultural spectacle, on the other hand, is characteristically large-scale and landscape-based (those competitive corn cobs being a notable exception, but even those form part of a large-scale spectacle in the show).

Landscape-scale sights are more relevant to a theory of agricultural spectacle, and there is a literature on this although it tends to focus on what humans find striking about landscapes in general, which is not the same as agricultural phenomena featured on landscapes. This literature provides us with a speculative theory of Darwinian aesthetics in which humans are evolutionarily hard-wired to be drawn to landscape features that improve reproductive fitness. In general, writes Appleton (1996), this means prospect -- an unimpeded view — and refuge - opportunities to hide from hazard. More specifically, writes Dutton (2009), there are crosscultural affinities to particular images of "landscape with trees and open areas, water, human figures, and animals", and specifically for the landscape to be blue.

I have doubts about the selective pressure on human appreciation for these landscape features and about how the preferences would have been preserved for so many millennia. ${ }^{4}$ But anyway it is difficult to imagine how any of these preferences would map on to what humans find striking about agricultural sights. Most agricultural phenomena intended to be striking do not do so through context-, culture- and informationfree impact on human hard wiring; instead they become spectacles only after some explanation, or "captioning", and with effective captioning even mundane sights can be elevated to spectacle. As an Art History student I saw a drop of paint turned into a spectacle. This was in a course on Impressionism taught by

\footnotetext{
${ }^{4}$ Actually I would expect the information richness of a vista to be more valuable to these primitive aesthetes than the color blue or the presence of water. I have a vista point on my farm in the Blue Ridge Mountains where every visitor is instantly captivated despite the landscape not being blue (the name of the range notwithstanding) and not featuring water. What it does offer is extraordinary information richness: you can make out dozens of farms, forests, fields, mountain peaks, and roads.
} 
a charismatic young woman who would launch into captivating narratives that could get the whole class excited about the avant garde composition, about the never-before subjects, and the rebellious use of color. I remember us pouring over a portrait one afternoon and she had us enthralled with the pathbreaking palette of colors. What's red doing in there? And up here, yellow... and here in the subject's hair, the pièce de résistance: purple! Heads were literally shaking as we marveled at a single dab of purple paint she had managed to render spectacular. (Obviously the painting itself had spectacular value on its own, or it wouldn't be on the screen in a lecture hall over a century later... but that brushstroke had never been a spectacle before. Such is the power of skilled captioning.)

The world of agriculture is rife with captioned spectacle; depending on the nature of the sight and on the viewers preconceptions, this may require extensive or brief captioning. When PBS correspondent Fred DeSam Lazaro went to Kenya to report on the NGO One Acre Fund, he needed a visual representation of the charity's supposed revolutionary impact on local farming. Wearing one of the khaki vests that seem to be issued to all journalists upon entering Kenya, Lazaro positioned himself in a spot on the landscape that "illustrates the difference One Acre Fund can make." Lazaro gestures to a "typical smallholder plot" with "pretty randomly planted cornstalks", and then brings the camera over to a One Acre field which, "as you can see", had better yielding plants arranged in the neat rows familiar to North American viewers (Figure 4). Thus captioned, an ordinary small corn field becomes a spectacle of agricultural modernity and a Westernscientific correction of backward African farming (never mind that the "neat rows" were actually pointless in a plot being cultivated by hoe, as this one was).

To an American audience accustomed to tidy row crops - most Americans see the landscape of flyover country as endless neat linear monocultures even if they can't identify the crop - the One Acre plot could be imbued with spectacle value with only a brief caption. Conversely, what I teach my students about African farm plots is the diametric opposite, and it takes much more work. At first blush they see the projected image of a Kofyar intercropped field as unsightly and disordered, with connotations of backwardness. But then we discuss the ecological complementarity of pearl millet (Pennisetum glaucum) and sorghum (Sorghum bicolor); the benefits of vertical layering; the economic strategies reflected in the crop mix; and the value of fields that can be worked with simple sustainable technology rather than expensive machines (Stone et al. 1990). Then, when we return to the image of the Kofyar intercrop, I hope to have rendered it more comprehensible and admirable, and if I could muster my art history professor's charisma, perhaps it would even become a bit of a spectacle. If a dab of purple paint can, why not a field of grains and legumes?

Joel Salatin, the widely publicized "most famous farmer in America", has been entrepreneurial at imbuing his Polyface Farm with spectacule value. This does require captioning, but he has access to various forums for making his case. Figure 5 shows one of the Field Days he hosts regularly, this one attended by 1,700 people (at $\$ 100$ a pop; you do the math), at which he stands atop a tractor with a bullhorn narrating successive agricultural tableaux. The farm is mainly composed of extensive grassy fields, and careful attention goes to spectacularizing the grass itself. He convinced Michael Pollan (2006) that the grass was his real crop, and he describes the grass as a "salad bar" in books, on tours, and in the marketing of the cattle that feed on it ("Salad Bar Beef"). On the tour I was on, Salatin bristled when one guest asked him about using selective herbicide on the fields, as the suggestion of weeds disrupted his urging the crowd to marvel at the beauty of his fields.

The captioned spectacularization extends to the very commonplace scene of cattle grazing in a field. Repeating what appears in his writings and videos, Salatin exhorted the Field Day crowd to appreciate in his cattle three characteristics of herbivores: mobbing (for predator protection), movement (for fresh forage), and foraging. Following this captioning, the field on which some cattle were grazing and others lying in the shade of a tree (supposedly mobbing, but really just lying in the shade of a tree, which cows do either individually or in various-sized groups) was spectacle enough for dozens of attendees who snapped excitedly with cell phone and cameras (Figure 6). 


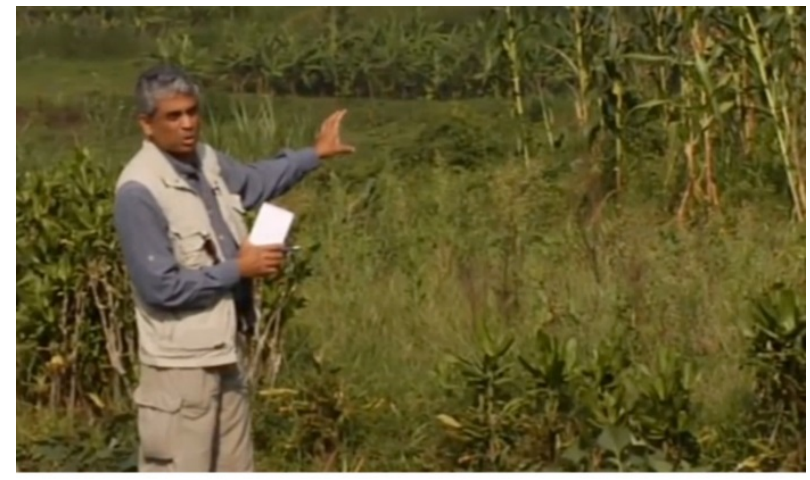

The "typical smallholder farm" has

"pretty randomly planted cornstalks."

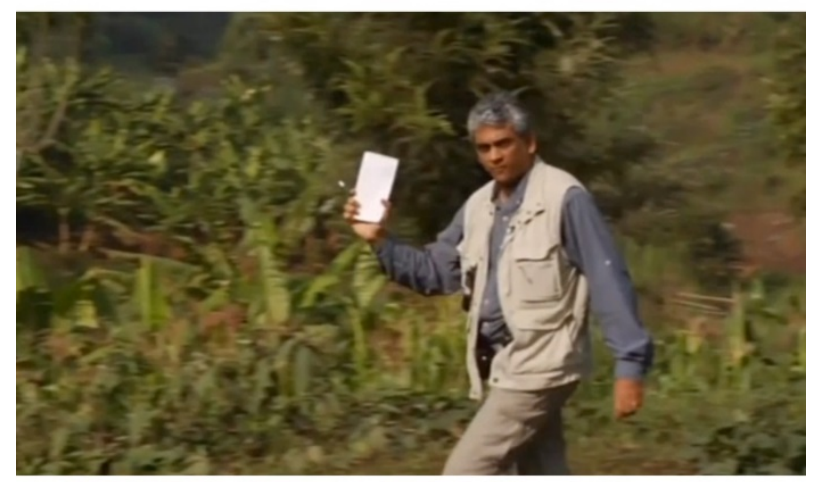

But right over here...

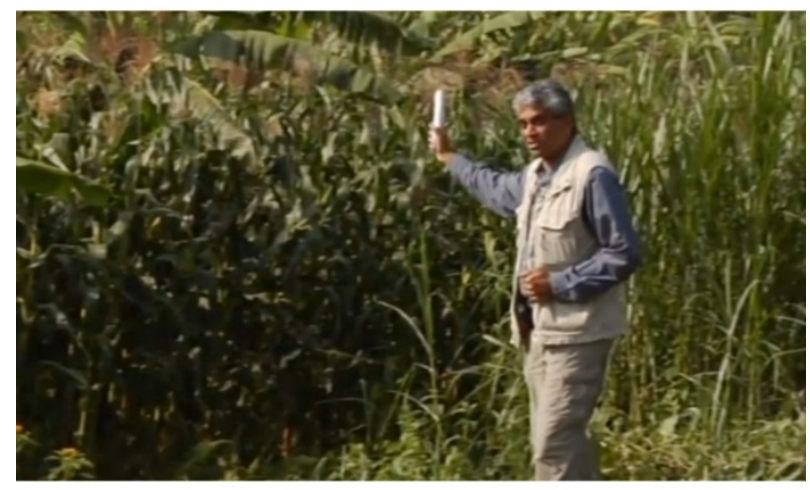

the corn in the NGO member's farm is

"planted in careful rows".

Figure 4: PBS correspondent Fred DeSam Lazaro reporting in Kenya (PBS Newshour 2012). 


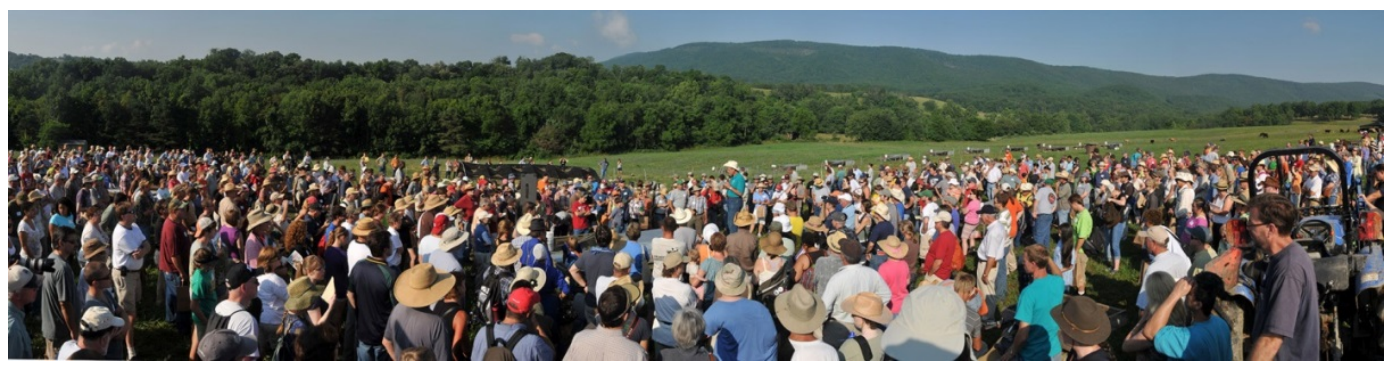

Figure 5: At a lucrative Field Day, Joel Salatin captions the spectacle at Polyface farm. (C) G. Stone.

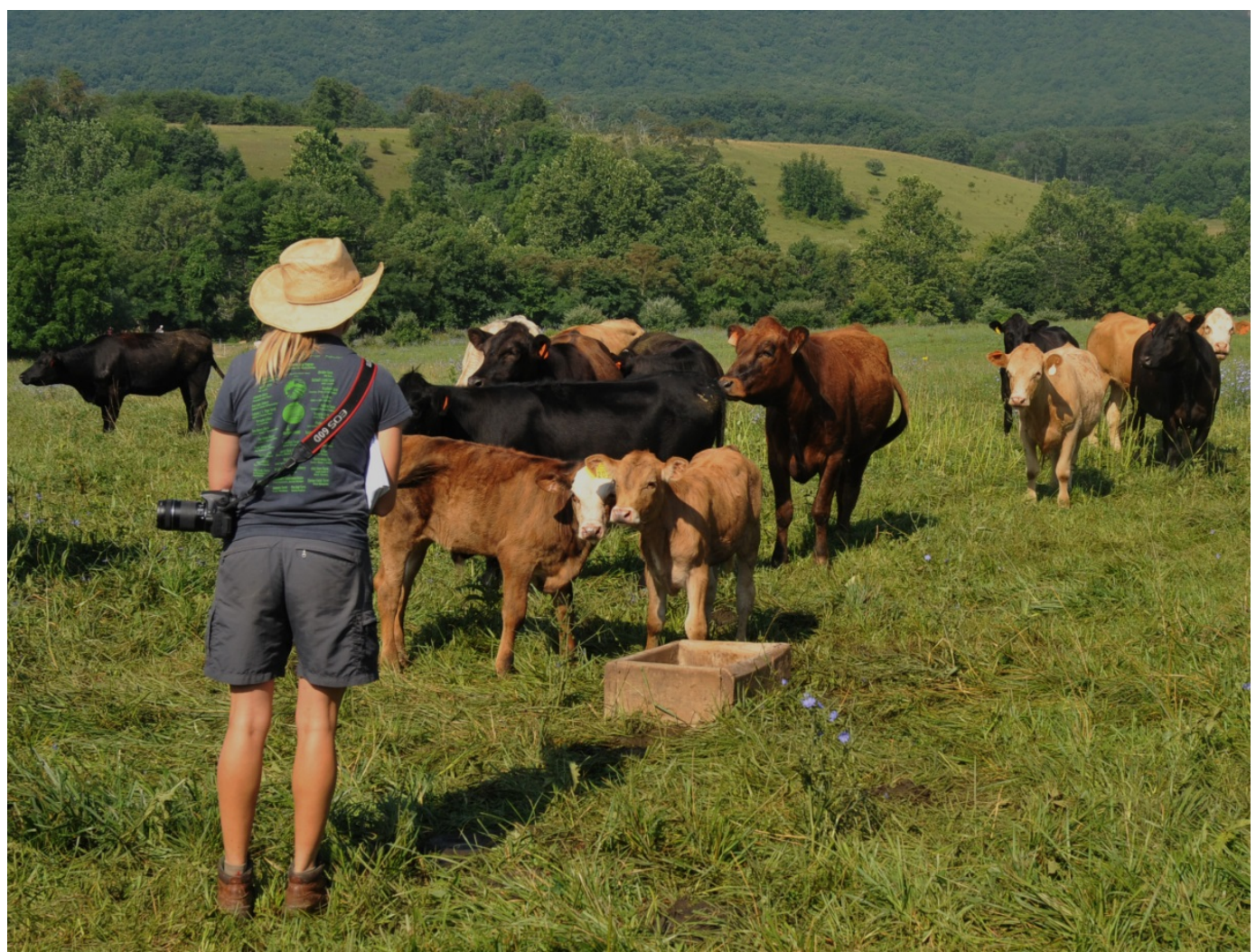

Figure 6: A Nikon-slinging attendee at Polyface Farm Field Day admires and photographs grazing cattle. With enough captioning, quotidian cow behavior becomes a spectacle. (C) G. Stone.

An example of agriculture that serves as a spectacle with much lighter captioning is the Chengtoushan Archaeological Park in China. It is intended to attract visitors to boost the local economy and to educate about the long history of rice agriculture, which it does with walkways over active rice fields (Figure 7). The park was named World Landscape of the Year in 2017 (Jordahn 2017). 


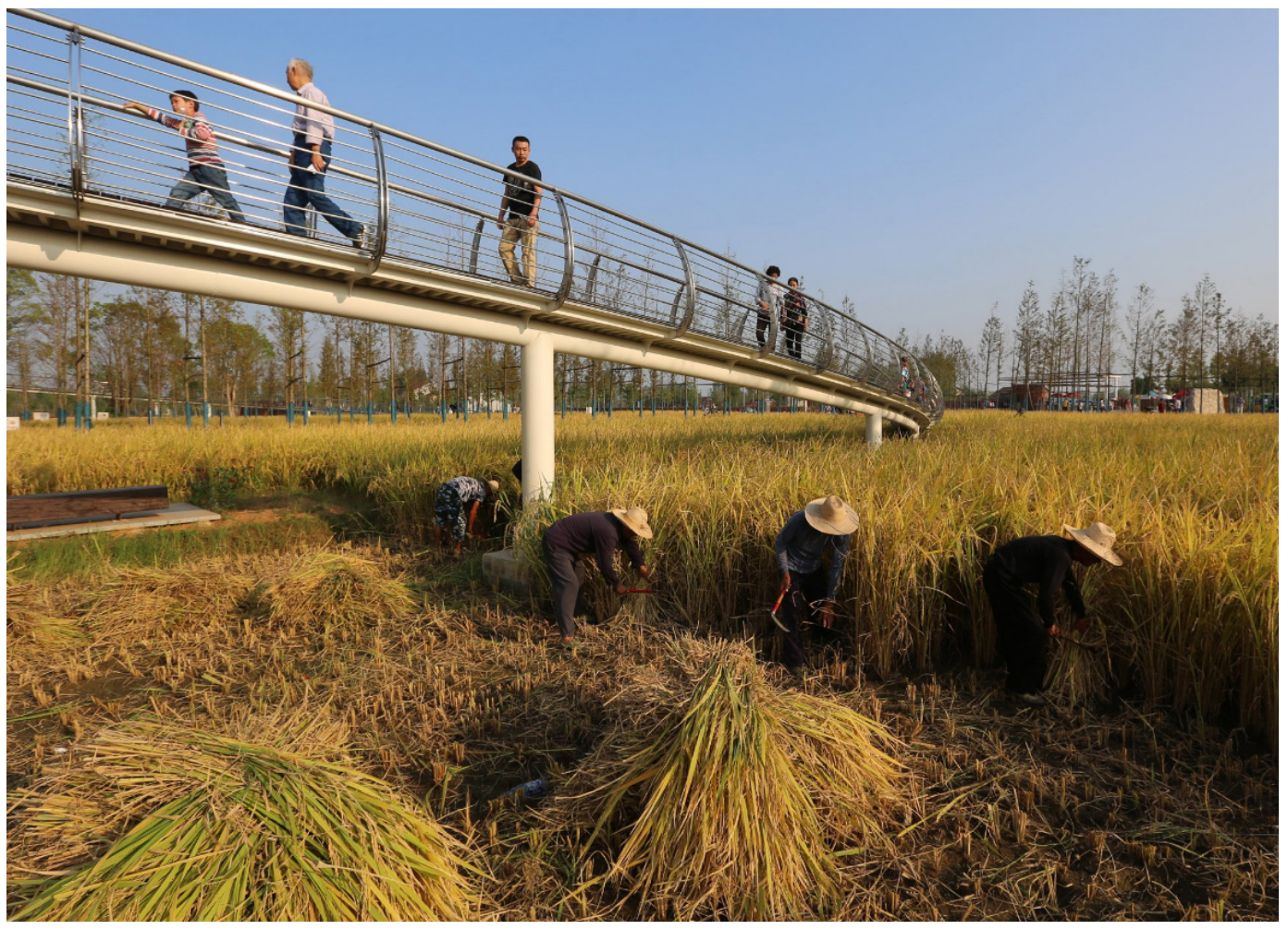

Figure 7: Chengtoushan Archaeological Park. Source: Jordahn (2017)

Beyond the captioning that is central to the creation of agricultural spectacle, there are distinctive features of farming that make various kinds of spectacle key for transmitting information about what is happening on the farm. Particularly important are the part-whole relationships considered in the next section.

\section{Scale and synecdoche}

Much of Tversky and Kahneman's analysis revolves around the biases to which heuristics in human thought processes are prone. In statistics, bias generally refers to nonrandom disagreements between samples and populations: no one measurement is expected to indicate the population parameter of interest, but unless there is bias - multiple sample measurements will converge on the population parameter. Most of the biases in Tversky and Kahneman's analysis also pertain to part-whole disparities. Part-whole disparities are important to us because in agriculture, spectacle is often more effective at scales different from actual operational scales. The use of spectacle at one agricultural scale to accomplish ends at another is sufficiently common as to deserve a label. Lefebvre (1991) coins the uses the term spectacularization for when "a part of the object and what it offers comes to be taken for the whole." Slater (2002: 220) uses the term gigantification for the process of exaggeration, "whereby a selected fragment comes not just to represent, but to erase the larger whole to which it belongs" (Igoe 2017). But I will suggest that the better term would be synecdoche. Synecdoche - which is a touch pretentious, but at least it's English, unlike pars pro toto refers to a part standing for the whole (or, confusingly, the whole for the part). As it occurs both in time and space, let us consider both temporal and spatial synecdoche.

Temporal synecdoche refers to the fact that the most important outcomes of agriculture unfold over time scales of months or years as noted above - much too long to provide spectacle. So agricultural spectacles generally represent only a part of the production cycle. The test plot is viewed fleetingly; the corn 
cob is a moment of crop development frozen (actually dessicated) in time; the pesticide demonstration shows dead insects today, not next year's resistant offspring. Viewers are obviously aware they are seeing a small sample of the phenomena of interest, and they may know it is not a representative sample, but the image may still serve as a heuristic and shape their view of longer-term results. (Kahneman (2011) provides many examples of this sort of thinking.) I discussed this with an Australian cotton farmer once; he described farmers coming to see demonstration plots with wonderful looking bolls but unknown input costs. Some were impressed but he scoffed at the notion that he should be impressed by the healthiness of the bolls, as the only thing that mattered was the bottom line at the end of the season. Only then could one know if they had been "buying the yield" — the term used for a yield increase resulting from equivalent input costs.

Spatial synecdoche refers to the fact that spectacle is obviously sensitive to physical scale, with greatest effect most commonly being achievable at scales smaller than the one at which production occurs. The Corn Shows are an obvious example of smaller-scale spectacle because the cob is at a smaller scale than the plant, which is at a smaller scale than the productivity of the field, which is only one component of the economic returns to the field. But the Corn Shows also exemplify how agricultural content can be used to create a scale that does not exist in the actual conduct of agriculture: the small-scale cobs are collected into a dazzling large-scale array in which selected output from hundreds of farms are concentrated into one space (discussed further below). It is only because of this larger concocted scale that the individual ears become spectacular enough to attract attention; it is hard to imagine anyone going out of their way to see one farmer's ears of corn, no matter how plump and even the kernels. ${ }^{5}$

Nonrepresentativeness and rigging. If agricultural spectacle tends to embody temporal and/or spatial synecdoche, it always faces problems of representativeness, which is a leading source of bias in how problems are evaluated (Tversky and Kahneman 1974). This does not mean that spectacle is inherently rigged, but that it grows out of the common habits of thought that Tversky and Kahneman identify. I would define agricultural spectacle as rigged if it is created by manipulating conditions that observers would not normally expect to be, or does not know are, manipulated. It is a continuum. The spectacle of Chinese children standing on top of wheat plants during the Great Leap Forward, supposedly demonstrating the hyperdense planting recommended by the quack scientist Lysenko, was shamelessly rigged (Figure 8).

This is an extreme. The demonstrations in which Green Revolution hero Norman Borlaug fertilized both semi-dwarf and conventional wheats so that the latter lodged (described below) were rigged, but less brazenly so: the semi-dwarf varieties really did stand upright and yield well when heavily fertilized. The problem was they weren't any better without heavy fertilizing and irrigation (Baranski 2019), and anyway no one would ever dump that much chemical fertilizer on conventional varieties. Less manipulative yet would be the farmer field used as a demonstration of a new seed or input. Farmers who view the field - in India sometimes bussed in by the company behind the spectacle - reasonably expect the field to be on particularly fertile ground and to be getting extra care. Unless the company or farmer lies about the conditions, the spectacle is not so much rigged as simply oriented to capitalize on the human tendency to rely on nonrepresentative heuristics.

\footnotetext{
${ }^{5}$ In many cases agricultural phenomena that are too large-scaled to be visually wieldy can be rendered spectacular by concentration, as in the Kenya case above and Indian cotton case below. This visual concentration is not what concerned Debord when he wrote of concentrated spectacle; what was concentrated in Debord's view was the totalitarian power of a Mao, Hitler or Stalin (Debord, 1967), not the visual elements seen by subjects. However such totalitarian regimes often put on periodic displays that bring together key elements of their power into spatial synecdoche; the most glaring example would be the military parade which simultaneously highlights the size of the regime's military force, its equipment, its discipline, and its loyalty.
} 


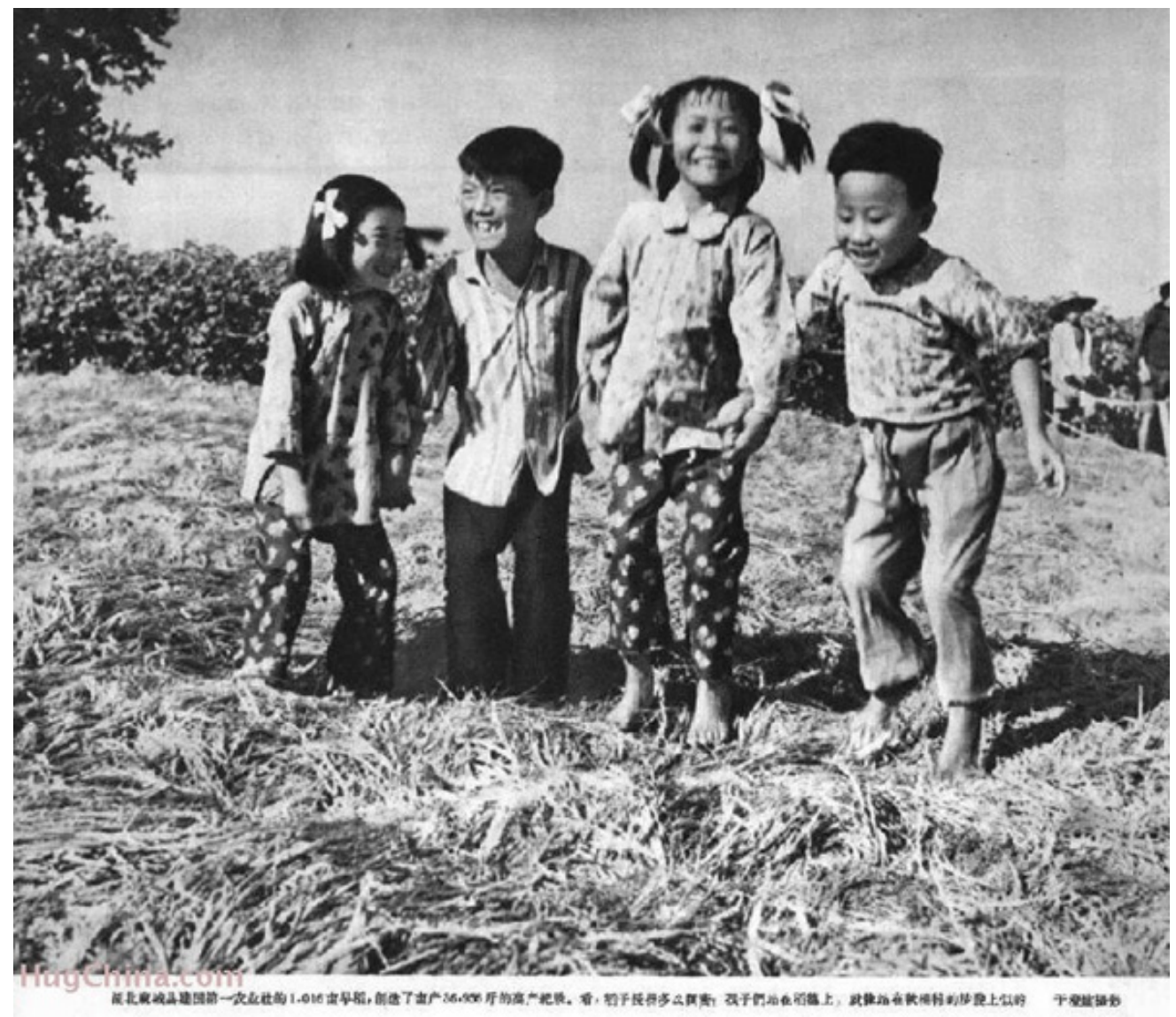

Figure 8: Propaganda photo during the China's Great Leap Forward intended to show a proper wheat field in which the plants were so closely planted that children could stand on the plants. The children were actually standing on a table.

\section{Agriculture for show}

As we have seen, anything that is striking may be a spectacle, but the term may also connote something being created specifically to be watched — "specially prepared or arranged display"6, or "for show." In Rome, the spectacles watched from the spectaculum were entirely for show; without the spectators there would be no call for slaves to kill each other or for bare breasted women to spear boars (Jacobelli 2003: 17). In this sense the performances were the opposite of the audience-less agriculture performed by Richards' farmers. But while gladiator shows were ghastly, at least they were honest as being pure spectacle. Not so agriculture and other activities normally performed for their utility function, for which the term "for show" has connotations of illegitimacy, as reflected in the thesaurus giving the synonyms "act", "affectation", and "frame-up."

Performances for show can usually be exempted from charges of illegitimacy by disclosing their showy nature, especially by including this information in its title. Thus a "show horse" is bred, bought, and managed with the intent of appearing in shows, and there is no shame in it being poor on the track or in front of a plow. Similarly, agricultural shows are entirely for show and they are pure explicit spectacle (Holloway 2005: 124). The agricultural show does not claim to be the actual performance of agriculture: cattle,

${ }^{6}$ https://www.etymonline.com/word/spectacle 
pumpkins, or sacks of grain are thrown together (Figure 9) and prize pigs are trotted in circles. The aims vary: it may be for a general burnishing of the agricultural imaginary (as in the British show days (Holloway 2004)) or the promotion of a particular area for agricultural immigration (as in the agricultural exhibits at the Montana state fair (Edwards 1999)), but it cannot be mistaken for actual farming.

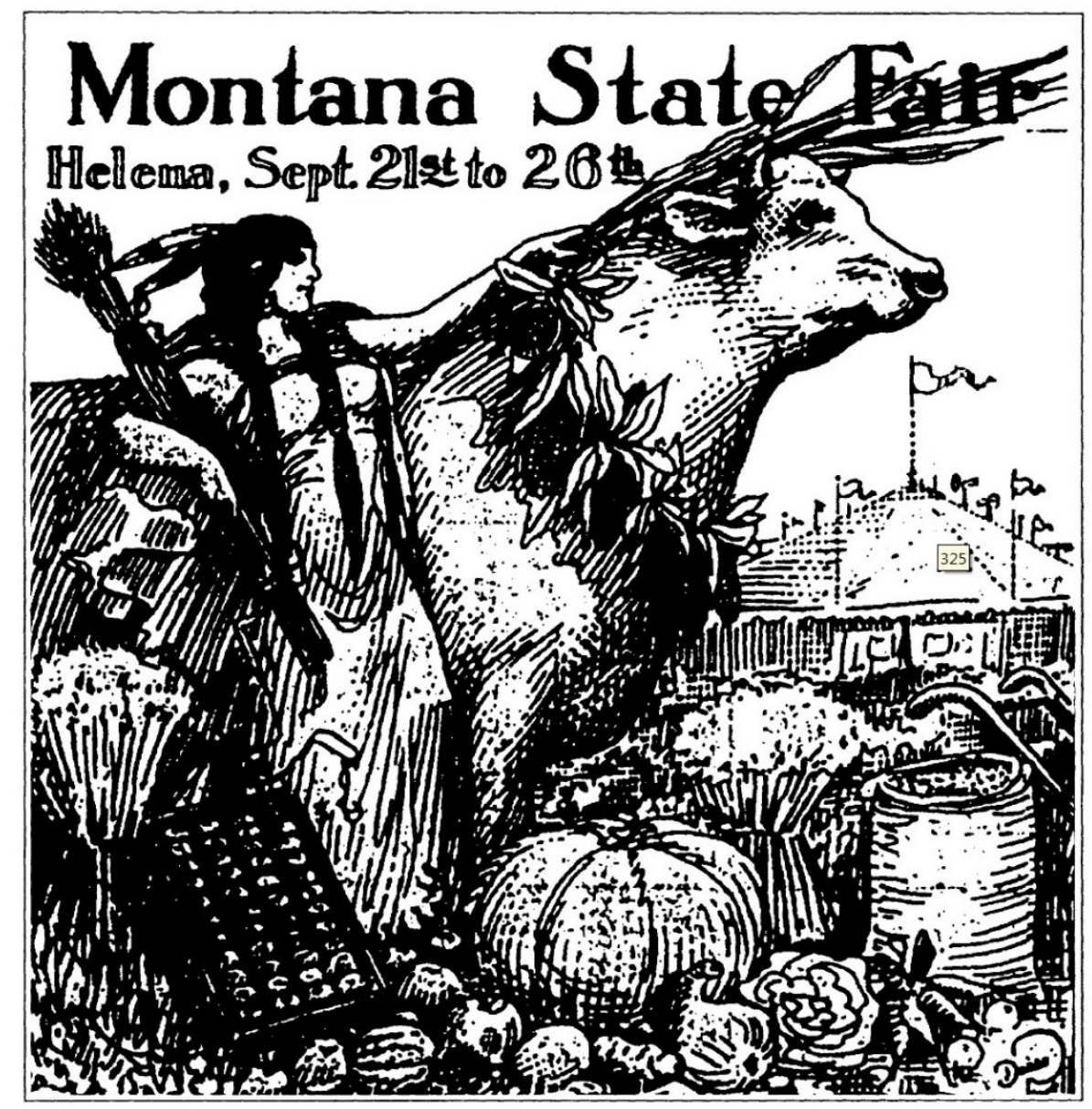

Figure 9. Advertisement for the 1914 Montana State Fair. Source: Edwards (1999).

The term "demonstration farm" is sometimes used to disclose an operation organized along show rather than utility lines, but it is nevertheless a farm instead of a pure show. Conversely, farms that fear being considered show farms often insist on self-labeling as "working farms" to claim utility function, often obscuring the fact that the farm also has important show functions. Polyface Farm, for instance, insists it is a "working farm" and not "for show", a protest it apparently feels necessary because it opens itself up so aggressively to public audiences (Figure 10). However it most definitely has show functions: some of the production methods like "Pigerator Pork" that thrilled Pollan, farm visitors, and Youtube watchers, are practiced only at Polyface itself and not at the numerous other farms on which Salatin produces the food he sells. 


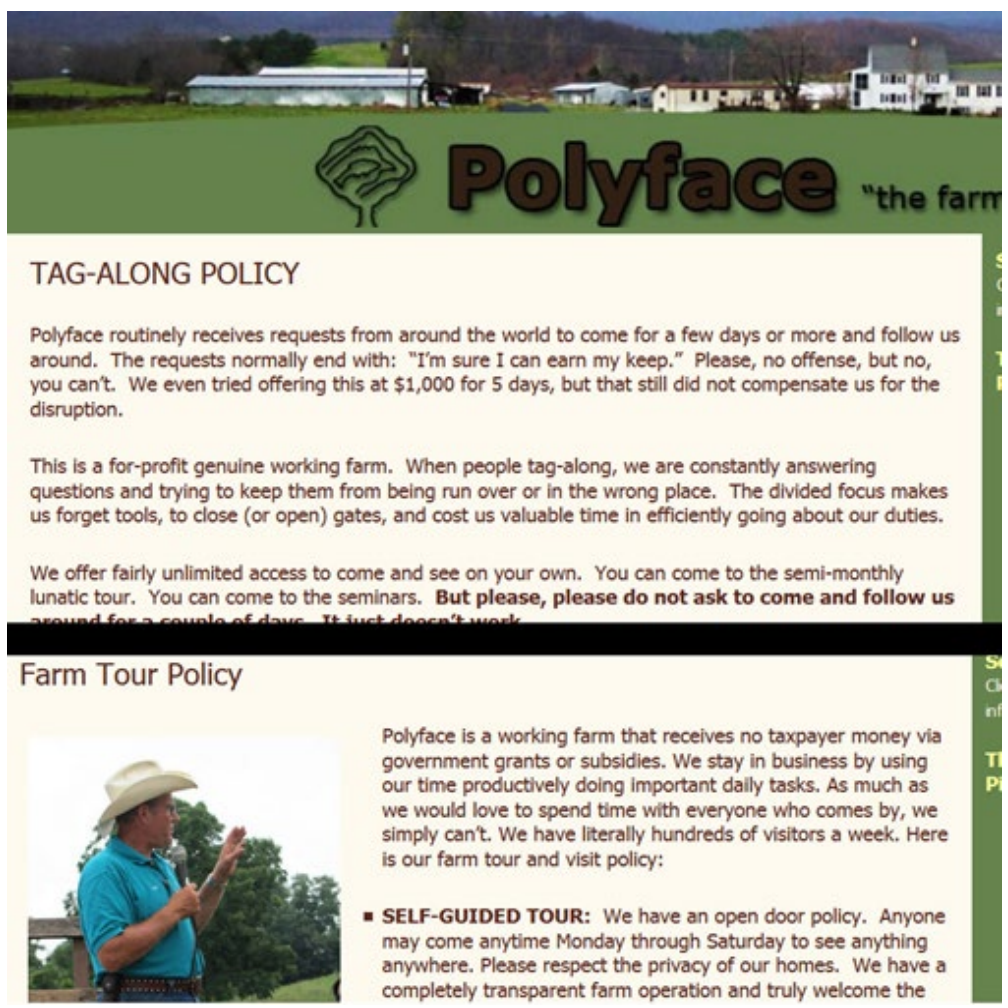

Figure 10. Examples from its website stressing that Polyface is a "working farm." This representation, reinforced by the Thank-God-I'm-A-Country-Boy-like emphasis on "important daily tasks", serves to blunt the suspicion that any utility concessions are made "for show." In fact many of the most important tasks pertain to marketing activities that hinge on the farm spectacle.

Is show versus utility a valid dichotomy? Perhaps in some cases. Once on a trip to Wales we booked rooms at a B\&B (Bed and Breakfast) listed as being a working farm. The house frau who ran the B\&B was exceedingly gracious interacting with her tourist guests. When this guest inquired about the working farm, she took me to her kitchen where her burly husband Bernard sat slumped in a chair in his manure-caked wellies. When introduced, Bernard merely grunted, and when she asked if her guests could see the working farm, he gestured towards the door and said, "Go on then." The listing under "farm B\&Bs" had been entirely her doing, and Bernard was making a show of not farming for show.

But the more common state of affairs is that the purely utility functions of agricultural production are entangled with, rather than conceptually separable from, the spectacular functions. In a small sense, farmers create spectacles for which they are the prime spectator because visual appearance of the cultivated field generally serves as a farmer heuristic. As noted, humans use heuristics in most of their thinking (Tversky and Kahneman 1974); lush green uniform fields, for instance, may have a striking visual impact on the farmer because these qualities have been captioned as indicators of healthy production.

\section{Intent of agricultural spectacle}

When agriculture is intended for visual impact it obviously has a desired effect on an audience. The desired effects are quite variable: spectacle serves many masters. We can recognize different components, although they overlap. 
Political: expression and creation of power. Particularly at large scales, agricultural spectacle can serve a political master. Debord emphasized how spectacle not only mediates but constructs power, or as Capriotti and Kaika (2008) put it, spectacle is a form of discourse in which "power is not just expressed, but also formed." Well, it tries anyway. Agricultural spectacle does not necessarily construct or articulate power because, even when concern for visual impact drives agricultural practice, the impact of the visual on power is highly variable. It has much to do with the political entity or system being promoted by the spectacle. For Debord, the beneficiary was diffuse enough to never be explicitly named, but it encompassed capital and the political ideological systems supporting capital. One of the most important case studies in agricultural spectacle did serve a master almost as diffuse: both ends of the Green Revolution - Borlaug's wheat in Mexico and IRRI's ${ }^{7}$ rice in the Philippines - were rolled out as "spectacles to dramatize the fruits of modernity" (Subramanian 2015: 18), "consumerism, allegiance, and order" (Cullather 2010: 159), and in particular modern agricultural science. And both ends also explicitly identified the pivotal importance of the spectacle.

The leading Green Revolution spectacles occurred at the level of the test plot and the audience for the spectacles was threefold. First were the government policy-makers: Borlaug believed these people needed just as much of a "shock" as the farmers before they would embrace input-intensive market farming (Cullather 2010). Unlike most Green Revolution fetishists who fêted his seeds as inherently superior and "high yielding", Borlaug admitted that yields came from changed government policy and that the real role of the seeds was to spark change with spectacle. "The genius of the dwarf seeds", as Cullather puts it, "was to create a cultivar that was at once so spectacularly productive and so needy of the kind of inputs only government could provide" (2010: 267). The officials for whom the spectacle was intended were those in the global south, such as Philippines president Aquino who was most impressed by "how the rice looked" (Cullather 2010: 159). The US government was in on the show; President Lyndon Johnson visited IRRI in 1966, where he took a break from escalating the war in Viet Nam to squat among semi-dwarf rice plants and insist that the only war he sought to escalate was the war on hunger (Cullather 2010: 171) (Figure 11).

Second were the farmers, among whom Borlaug hoped that "spectacular increases in yield destroy in one stroke the built-in conservatism or resistance to change that has been passed on from father to son for many generations in a system of traditional agriculture" (Borlaug et al. 1969: 11).

Third were the funders who were delighted to have tangible visual presentation of results. Robert McNamara took the opportunity in his inaugural address as incoming president at the World Bank to marvel at the agricultural technologies that could "produce miracles in the sight of the beholder" (Cullather 2010: 160). Ford Foundation Vice President Forrest Hill gushed, "It's something you can see. You can say, 'Well go out and look at it.' It did happen" (Cullather 2010: 159).

Economic: selling to consumers. Anna Tsing (2005:142) uses the term "spectacular accumulation" for how "economic performance is conjured dramatically" in order to market business enterprises to investors on the frontiers of capitalism. Spectacle can play an important role in the marketing of farm enterprises, but the more common audience is comprised of consumers and what is being conjured is not economic returns but credence qualities -- i.e., product attributes that consumers cannot evaluate through normal use (Darby and Karni 1973). In North America the most prominent case of such economically-oriented spectacle is seen in Neo-agrarian enterprises, which need to capture a premium for credence qualities such as humane animal treatment, ecologically benign growing methods, and environmental sustainability. Opening up the farm to spectators allows customers to observe and appreciate these production values in a visually striking setting, and many Neo-agrarian farms advertise an open-door policy and/or offer farm tours (Figure 12). The problem is that farmers quickly find that opening the farm up as a spectacle takes a lot of work, especially since much on the farm only takes on spectacle value with a fair amount of captioning. Salatin of Polyface Farm, as noted above, has been particularly entrepreneurial spectacularizing his farm and he has helped to popularize the trope of the open farm (Figure 5).

\footnotetext{
${ }^{7}$ International Rice Research Institute.
} 


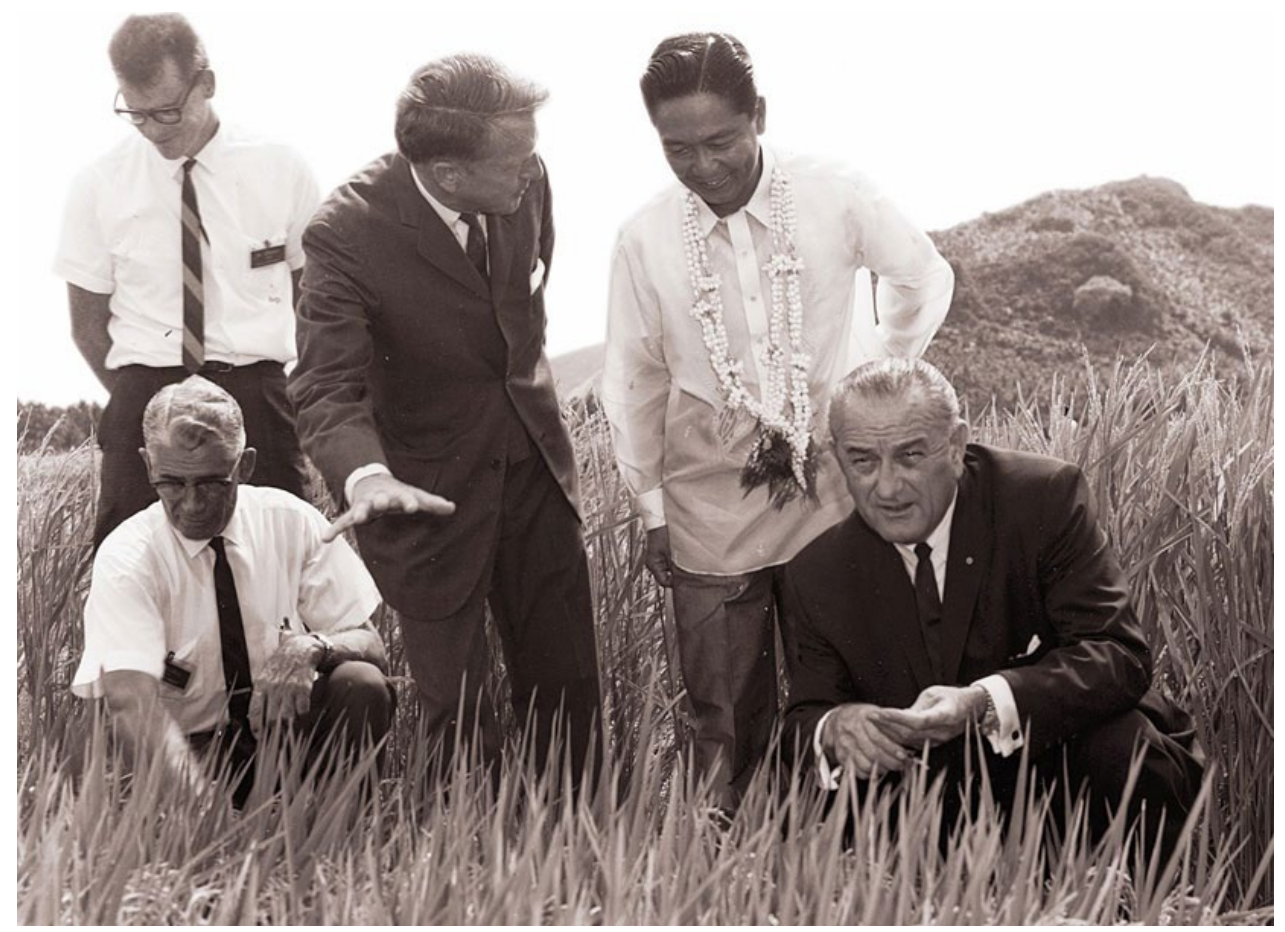

Figure 11: In this October 1966 image at an IRRI test field are (right to left) US Pres. Lyndon Johnson, Philippine president Ferdinand Marcos, IRRI Director General Robert Chandler, and two IRRI breeders. Source: IRRI.

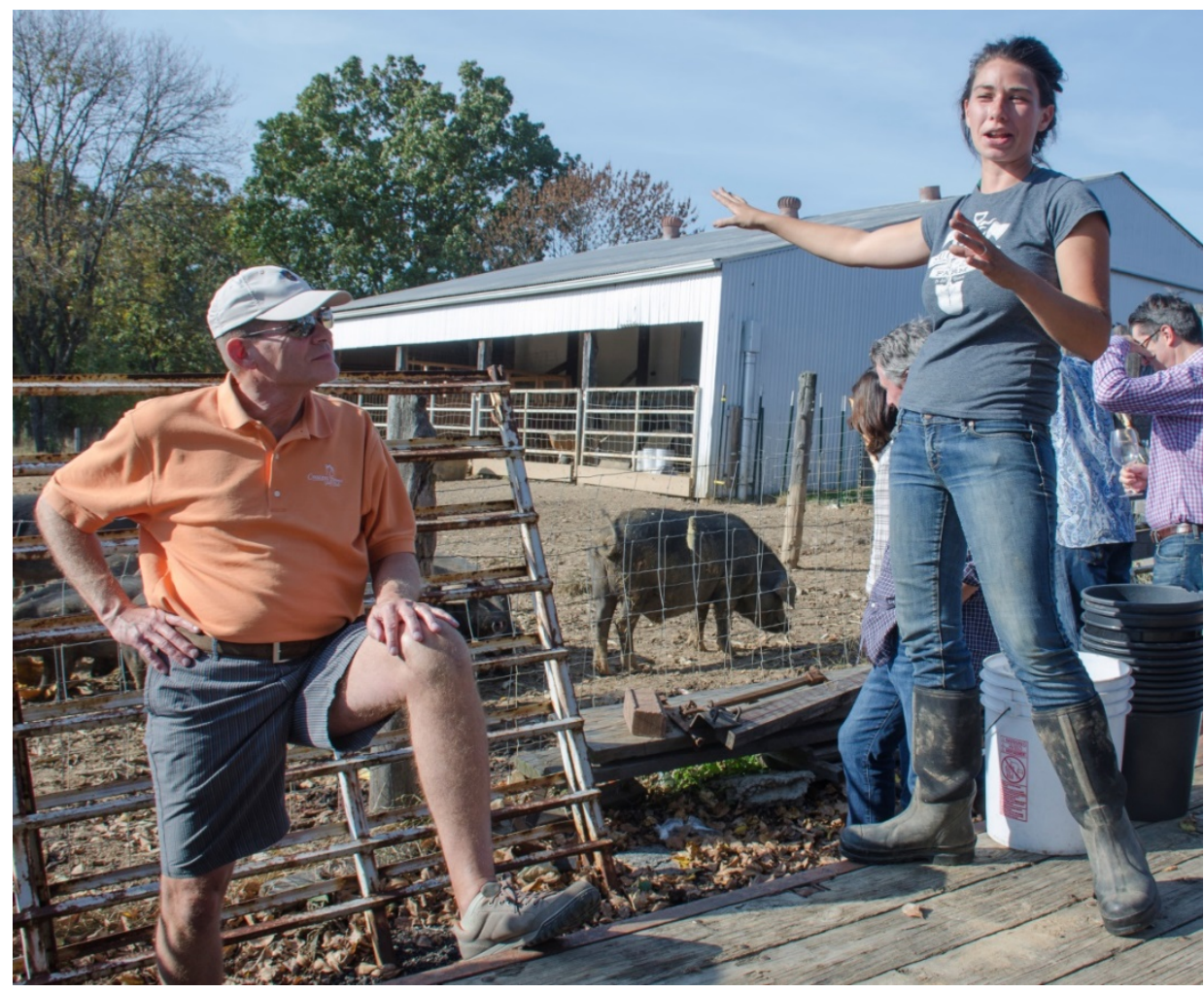

Figure 12: A Neo-agrarian farmer shows off her happy pigs during a farm tour. (C) G. Stone. 
But if the unsurprising behavior of Polyface cattle is spectacularized only with ardent captioning (as noted above), the astonishing behavior of dairy cattle in "pasture releases" has enough inherent spectacle value to draw enormous crowds in real life and on Youtube. The pasture release, an event mainly in northern Europe, features the Springtime opening of the doors to a barn where dairy cattle have been confined and stall-fed for the winter. The cattle leap, hop, run, and roll in the grass. Releases are announced beforehand, and tourists and camera crews show up to watch and record (Figure 13). The spectacle is particularly well organized in Sweden, where it is promoted by the dairy industry as "a perfect summer outing for the whole family", drawing hundreds of thousands of spectators yearly (Linne and Pedersen 2017: 113).

Although this spectacle does not require captioning, it can be and is captioned in diametrically opposite ways. Figure 13, on the Youtube channel for a dairy services company, captions the release as a show of the sheer joy of cattle; their aim is to burnish the image of the dairy industry. Figure 14, on the Youtube channel for a German organization promoting vegetarianism, captions the release as troubling evidence of the mistreatment of cattle by modern agriculture.

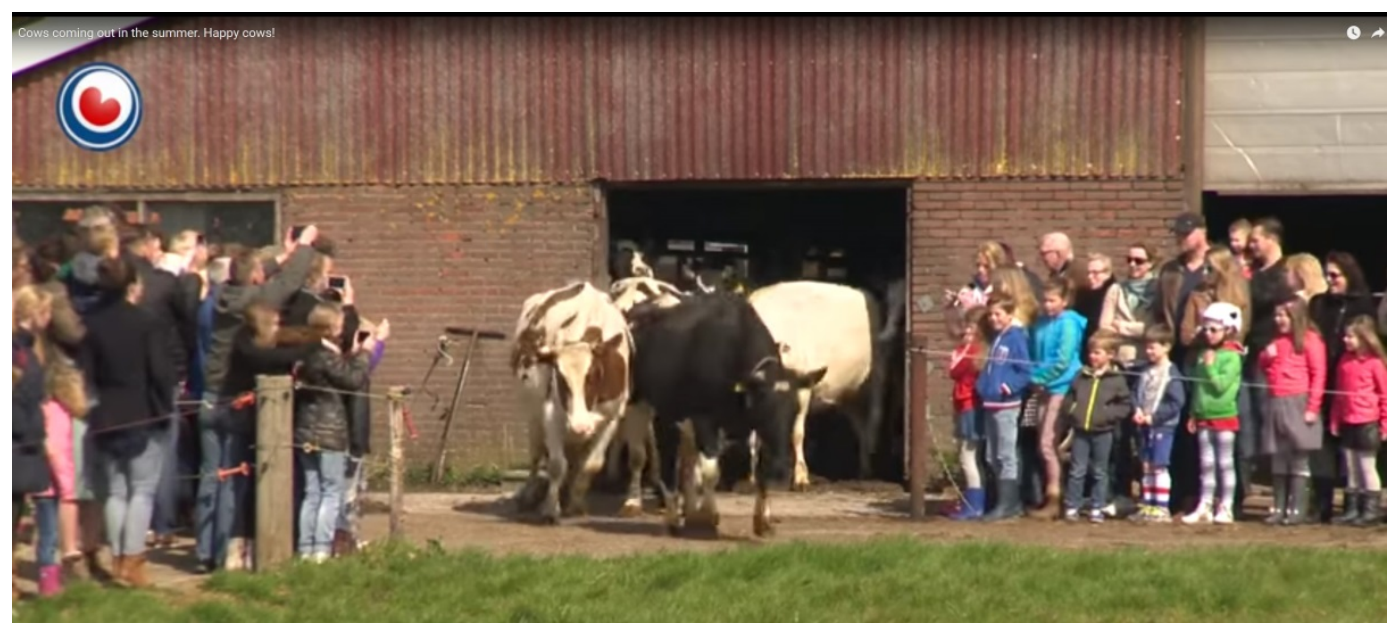

Figure 13: Barn release in Netherlands, posted by CowSignals Trading Company and stressing the joy of the cows. Source: CowSignals (2015).

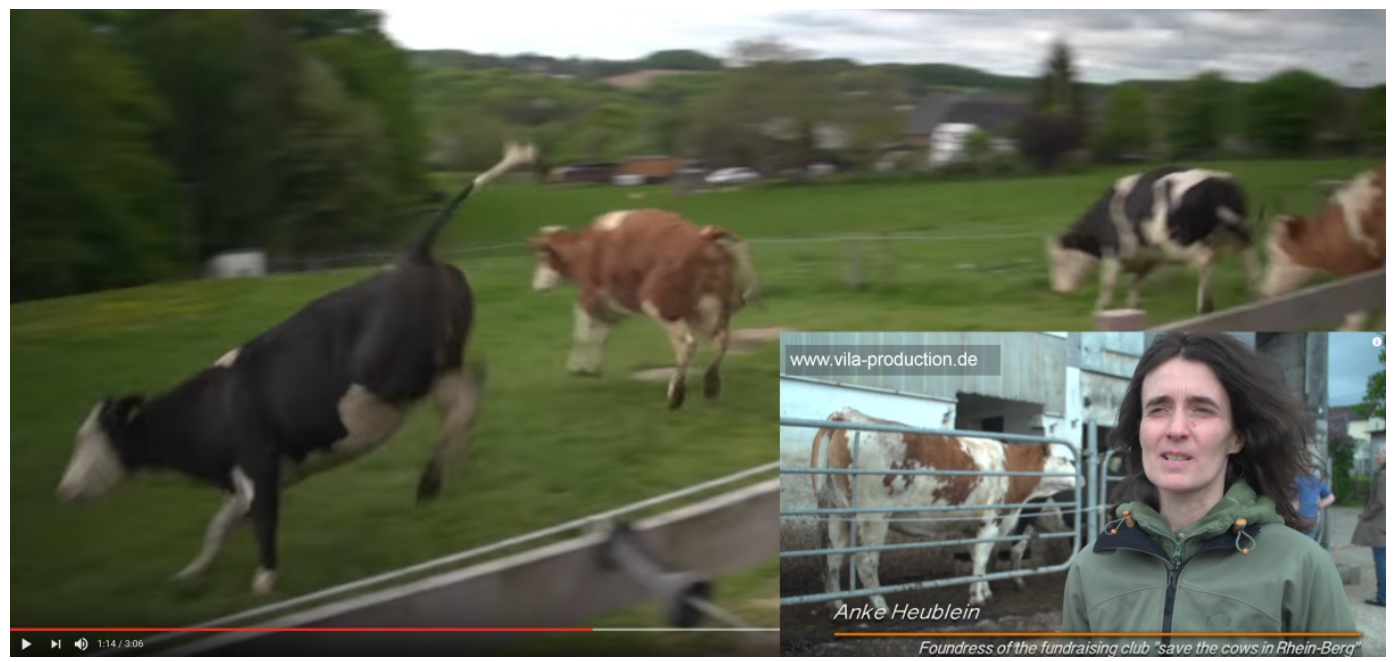

Figure 14. Stills from a German video by an anti-carnivory group using the spectacle of the pasture release to dramatize how miserable the cattle must have been in the barn. 
The release itself is not contrived "for show"; dairy cattle have to be confined during the northern European winter and have to be let out onto pasture in the Spring. Some countries even legislate pasture time for dairy cows. Yet Linne and Pedersen (2017), in their critique of Swedish pasture releases, challenge the reality of the animals at the center of the spectacle:

It could even be argued that the real cows and calves are not present at the pasture releases and open farm events. The animals that are actually there are rather signifiers, with functions to entertain, educate and promote the consumption of the real cows' bodily fluids. They are kept behind bars for children to look at and pet, turned into teaching material for parents to point at, and laughed at as they run out to escape their half year long confinement (Linne and Pedersen 2017: 123).

Social. I have noted that farms are on display for the local community which often acts as a spectating audience. Evaluating other farmers often relies heavily on the spectacle value of farm operations. Batterbury (1996: 17) writes that:

...the suite of performances embedded in a farm signals to a wider audience something about its owner in the same way a dwelling does. It may say, "I am rich, and have money for plows and fertilizer," or, "I can do all this, on my own," or, "I have perseverance -- my crops, through careful planting, survived the drought."

Thus, in discussing the construction of the identity of "good farmer" in Britain, Burton writes:

Farmers may also use the appearance or general 'tidiness' of the farm itself as an indicator of nurturing ability and according to one traditional farmer (farmer 56) a proxy for yield itself. When asked why farmers are concerned about the tidiness of their farms, he suggests: "You can't tell at the end of the day by how much he gets off his land. But, if you look at the farmyard and you look at the way he prepares and looks after the things there, surely it's going to be the same in his fields." (Burton 2004: 203)

\section{Scale of agricultural spectacle}

Agricultural spectacle can be surveyed not only along the axis of intent, but of scale. Let us consider examples of and distinctive features of spectacle at the scales of landscape, village, neighborhood, farm, plot, individual organism, and finally the invented scale.

Landscape. Entire agricultural landscapes can serve as spectacles and may even be created explicitly for that purpose, as we saw with Mussolini and the Pontine marshes. The Hachirogata Polder in Akita, Japan, is an interesting example in which not just the agriculture but the land on which it is practiced serves as a spectacle (Figure 15). Most of the 22,000 hectare Hachirogata Lake was enclosed by a dyke in the early 1960 s, with the aim of constructing a landscape that would showcase efficient modernist rice agriculture. Instead of the average 1.3 hectare Japanese farmers work on a part-time basis, Hachirogata farms were all 15 hectares and designed for full-time farming. Mechanization was pushed sometimes to the point of absurdity, such as use of helicopters to sow seeds. Farmers were recruited to take up farms between 1967-1974. But, ironically, Japan was (and is) short on seafood and long on rice, and Hachirogata farmers were soon being paid to reduce their rice production (Moore 1993; Wood 2012). 

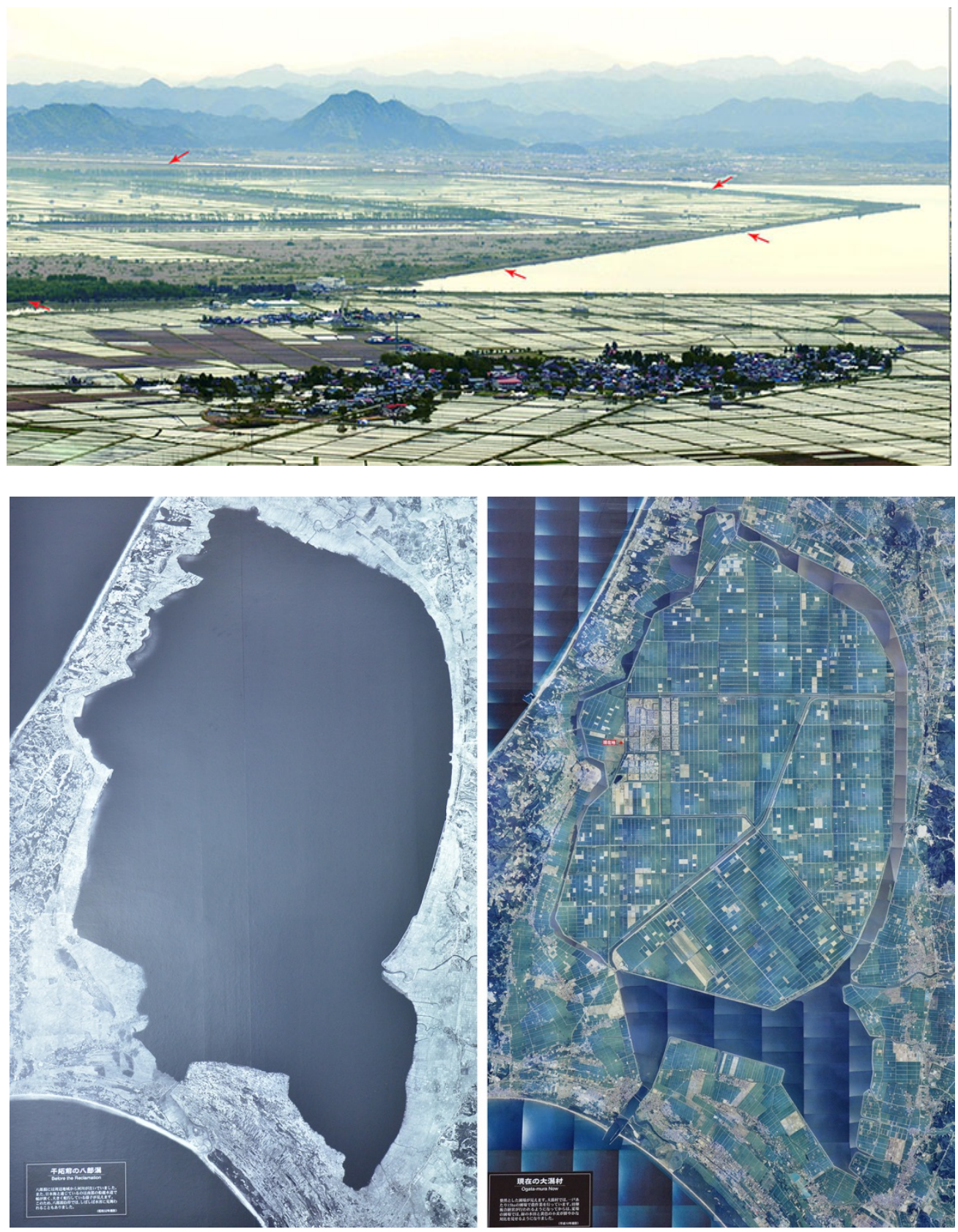

Figure 15: Top: View of Hachirogata Polder with arrows indicating the dyke. (C) G. Stone. Bottom: displays in the Ogata-muru museum depicting the created agricultural landscape.

Most of the Hachirogata polder continues to be worked by rice farmers, but it functions mainly as a landscape-scale spectacle and aspirational demonstration of agricultural modernity (Stone 2014). One farmer in particular serves as a "show farmer" (see below), and agricultural visitors are dutifully brought to watch him work. Figure 16 shows visitors from the Coalition of African Rice Development absorbing and photographing the spectacle, although what the Africans concluded by this demonstration of the benefits of industrial might, fossil fuels, and lavish government support, I cannot say. 

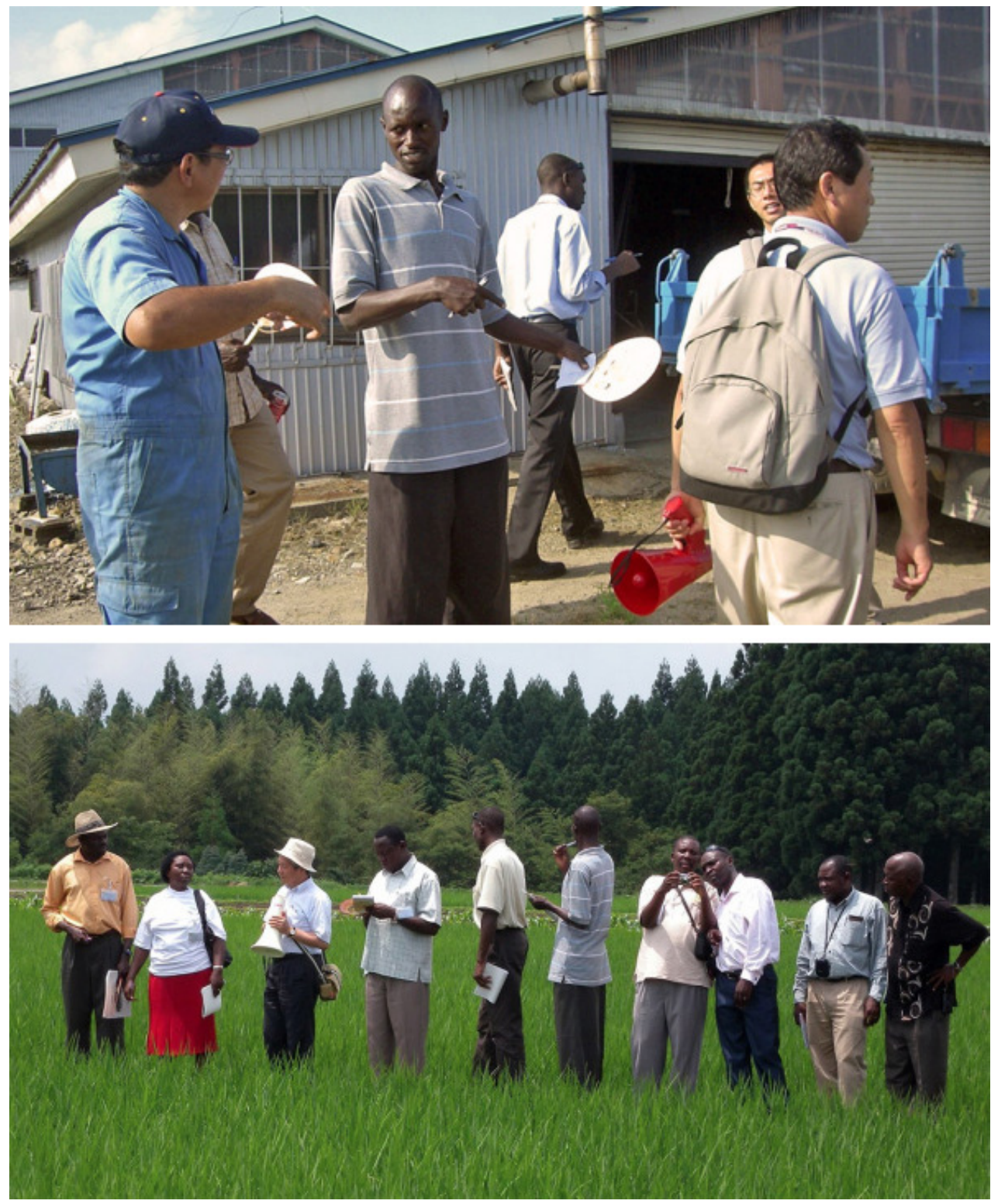

Figure 16: Visitors from the Coalition of African Rice Development at the Hachirogata Polder. Photo credit: Matsuhashi Hideo.

Problems of representativeness are not limited to top-down designs as in the cases of the Pontine Marshes and Hachirogata Polder. Suzanne Freidberg describes farmers in early 20th century New England creating a pleasing landscape of grains and pasture that turned it into a tourist destination. But the rural tableau was actually a byproduct of the rising demand for milk in the very cities the tourists were escaping. New England farmers were growing more feed crops to keep the cattle from going 'dry' during the winter; "a diet of hay and grain could keep them fat and lactating year-round" (Freidberg 2009: 207). But many farm homes became inns for tourists, capitalizing on the "idyllic and old-fashioned" appearance of the landscape.

Village. Development projects have honed the use of the village as a unit of spectacle. Robert Chambers argues that "project bias" in development is shown by the showpiece: "the nicely groomed pet 
project or model village, specially staffed and supported, with well briefed members who know what to say and which is sited a reasonable but not excessive distance from the urban headquarters" (2006: 20). Showpieces provide spectacle for foreign visitors, for senior officers to be impressed with subordinates' work, for investors, and for the press.

Chambers points out that showpiece villages direct attention away from the poorer people. In the terms developed here, the showpiece village is intended as a synecdochic spectacle for a larger scale of agricultural development. In order for the part (the village) to represent the whole (regional development), the spectators' gaze needs to be restricted. Chambers relates a wonderful example of a visitor managing to see beyond the scale of spectacle:

In the spring of 1961, Lyndon Johnson, then vice-president, was taken to see one of these villages in the neighbourhood of Agra. ${ }^{8}$ It was, of the several hundred thousand villages of India, the same one that Dwight D. Eisenhower had been shown a year or two before. It was impressive in its cleanliness, simple cultural life, handicrafts, and evidence of progressive agricultural techniques. Johnson, an old hand in problems of agricultural uplift and difficult to deceive, then demanded to see the adjacent village a mile or two away. After strong protesting words about its lack of preparation to receive him, he was taken there. This village, one judged, had undergone no major technical, cultural, or hygienic change in the previous thousand years (Chambers 2006: 20).

But showpiece villages vary in riggedness as defined above. What Johnson saw was rigged because the village was presented as an example of spatial synecdoche when it was actually unique. But a village may also take on "showpiece" or spectacular quality because it is unique. Enabavi, a village of 202 in Warangal District of Telangana, has earned a remarkable measure of fame as a one-of-a-kind all-organic village. Nearcomplete village level coordination is the result of strong leadership by a village elder and various forms of support from a local NGO, and the label of "chemical free village" (Figure 17) is considerably more compelling than simply claiming some organic cultivators. Enabavi has been visited, photographed, described, and analyzed by a parade of scholars (although they have used a pseudonym for the village) and the media (e.g. Ajith 2017: Misra 2009).

Farm and farmer. The farmer and his/her farm is a key unit for spectacle. The farmer or farm family may be particularly effective at captioning and may also be part of the spectacle. One of the very first conversations I had in rural Andhra Pradesh (in an area now part of Telangana state) at the beginning of my India research in 2000 was with the staff of an agriculture-oriented NGO. Their major project at the time was on NPM (non-pesticide management), an assortment of practices and simple eco-friendly technologies that supposedly allowed farmers to grow cotton without toxic insecticides. After listening to their description of the NPM program I asked to see their interventions in action, anticipating a farm and farmer selected (and groomed) for spectacle value. The staff enthusiastically packed into a car to take me to the farm of one Yakub, who did not disappoint. The reasons for the NGO's enthusiasm for this farm were immediately apparent. Yakub was a charming middle-aged farmer who spoke knowledgeably about NPM as he showed off his healthy-looking, largely insect-free cotton plants. The NGO staff then herded us to a perfect spot in the field where Yakub, with spouse and beaming children, could pose with me for a photograph that showed several elements of the NPM strategy: a bird perch, intercropped marigolds, and a pheromone trap (Figure 18).

\footnotetext{
${ }^{8}$ The etymology of Agra in Uttar Pradesh is different from the agra, the Latin term for field mentioned above. This name is derived from the Sanskrit name Agrevana, which appears in the Mahabharata, meaning "at the start of the forest" (agre $=$ the start of, vana $=$ forest).
} 


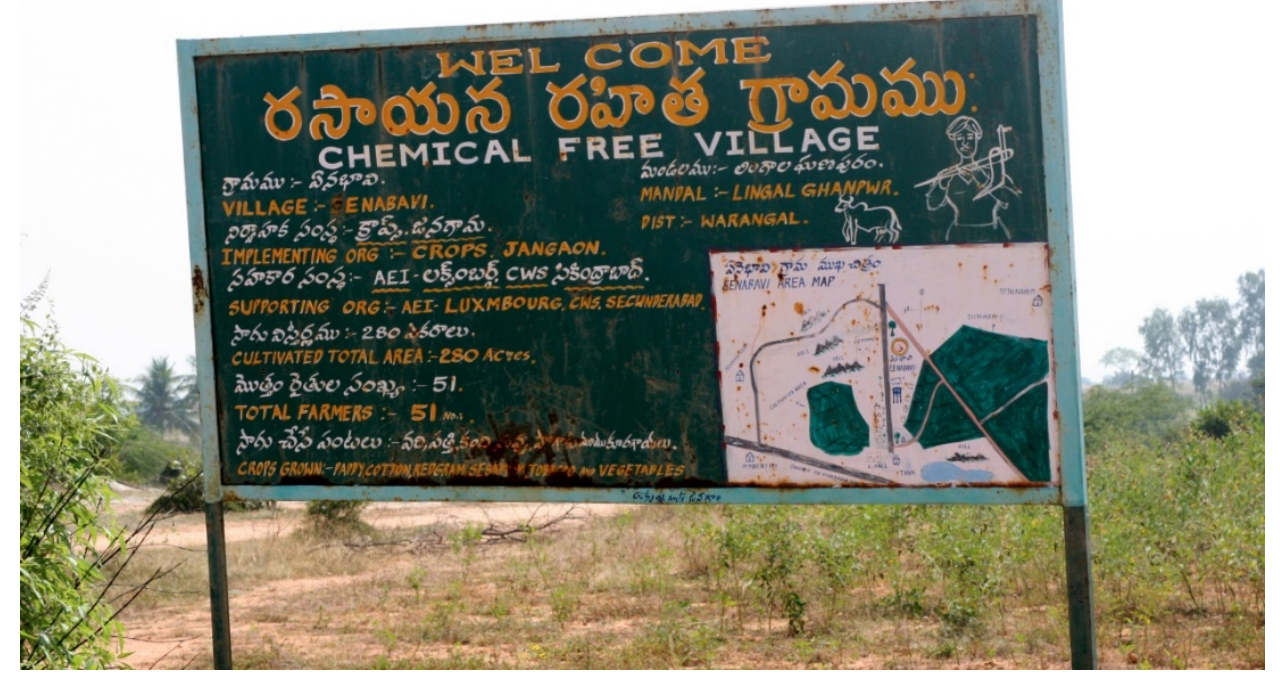

Figure 17. Signboard at the village-level spectacle at Enabavi, Telangana State, India. (C) A. Flachs.

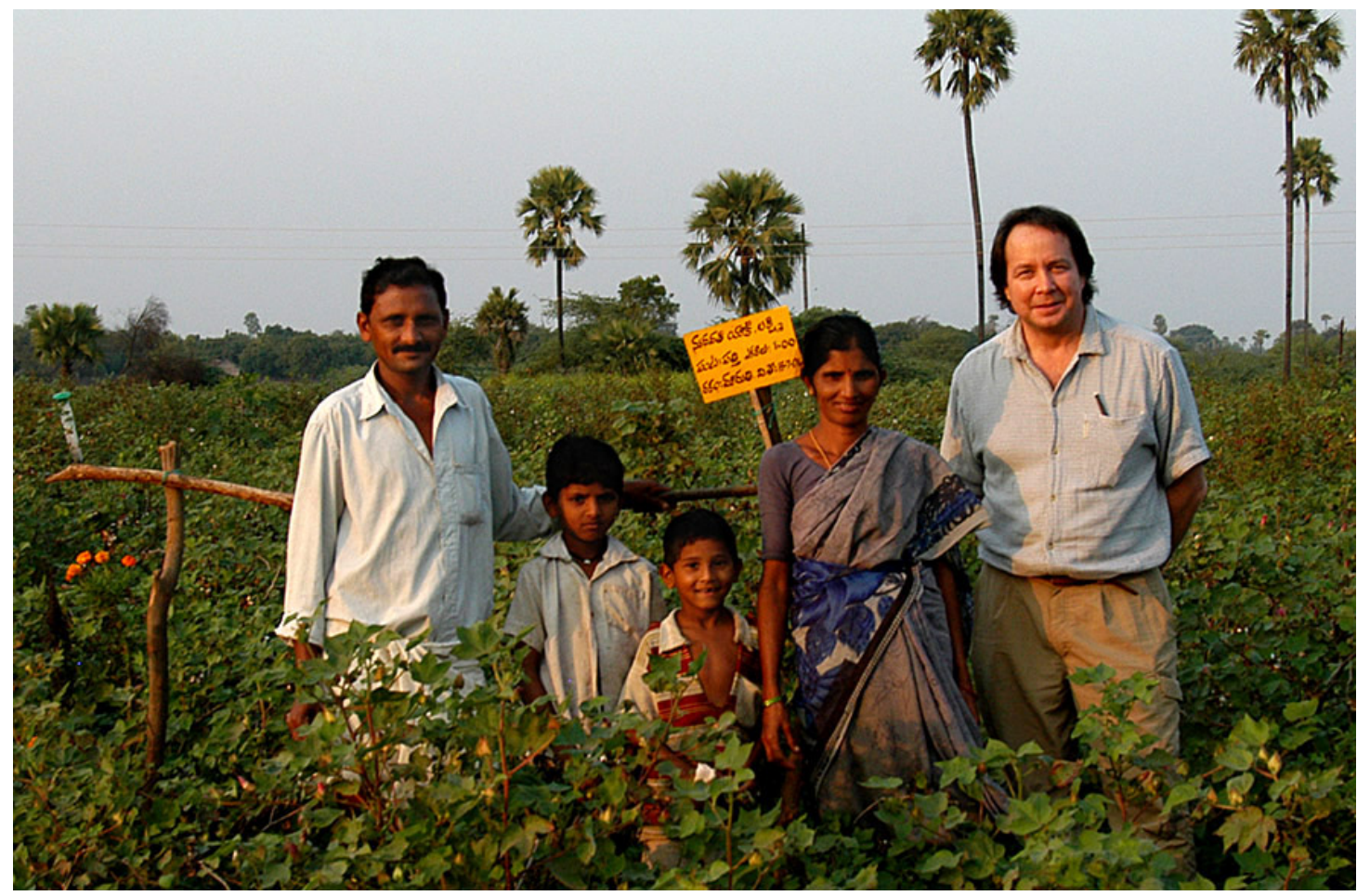

Figure 18. The author poses with Yakub and family, all of whom were well practiced show farmers. They posed at a spot where viewers could see three elements of organic farming: a bird perch, pheromone trap, and intercropped marigolds. Andhra Pradesh 2005. (C) G. Stone. 
"Show farmers" like Yakub (Stone 2014a) are in many ways the farm-level equivalent of what Chambers termed the showpiece village. They can be key in agricultural development projects and agricultural marketing, as seen in the Indian organic cotton projects analyzed by Andrew Flachs (2017). Yakub's coordinates followed Chambers' script for the showpiece: his farm was located away from town in a thanda (tribal hamlet) yet close to a major road. He had been on the payroll of the NGO. But he benefited in various ways from his role for the NGO: extra attention had been lavished on his farm so that his plants were flourishing to an unusual degree; he was also rewarded with local celebrity as an agricultural leader (a benefits Flachs (2017) also found among show farmers in organic projects). His farm displayed many key aspects of agricultural spectacle; the posing spot where we all hit out marks was a spatial synecdoche for the farm, and the farm was a spatial synecdoche for the NGO's NPM project. His farm was also a temporal synecdoche, with the continual discussion of "sustainable" agriculture obviously suggesting that the methods would be sustained and would even spread, and Yakub claimed many other farmers were following his lead.

Not surprisingly, Enabavi village - with its stream of camera-wielding visitors, boasts several show farmers. Visitors are funneled towards these synedocdochic farmers who are adept at showing off their organic methods and who also receive extra inputs and attention from a sponsoring NGO (Figure 19).

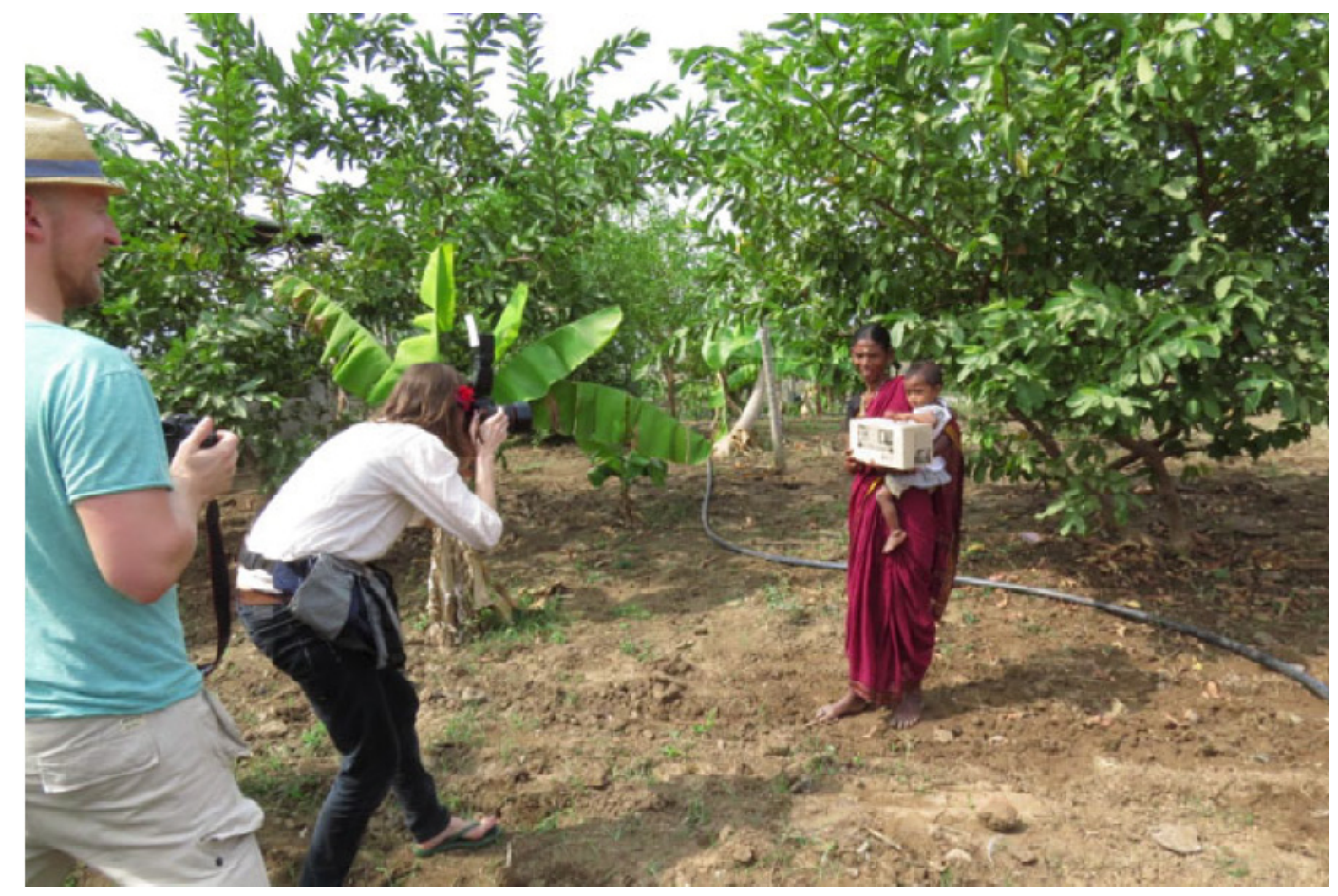

Figure 19: "Show farmer" in Enabavi. Source: Flachs (2017). (C) A. Flachs.

Plot. The individual plot is a fundamental natural unit occurring on farms and in research facilities, and it often exhibits interesting interactions between utility and show functions. In principle, agricultural scientists distinguish between tests or experiments, which are designed to generate data for the scientists, and demonstrations, which are designed for their rhetorical value (Maat and Glover 2012: 132). The two are commonly joined in "testing and demonstration" programs (e.g., Baranski 2019). But the distinction dissolves under inspection: Harro Maat (2011: 188) points out that demonstration is an inherent feature of all experiments, and Maat and Glover (2012: 132) explore how experimental plots may be designed for show. Glover describes Monsanto's smallholder project in India in which "test plots" were explicitly designed as marketing tools; the program official did not even understand the conceptual difference (Glover 2007: 165). 
While the Green Revolution provides a rich history of agricultural spectacle at various scales, some of the most interesting occurred at the plot level. Norman Borlaug was adamant that farmers needed to be "shocked" by spectacle and to this end set up the deceptive wheat demonstrations described above (Cullather 2010: 191). In India he had a like-minded accomplice in MS Swaminathan, who "structured field tests for psychological effect rather than clinical accuracy" (Cullather 2010: 202) (Figure 20).

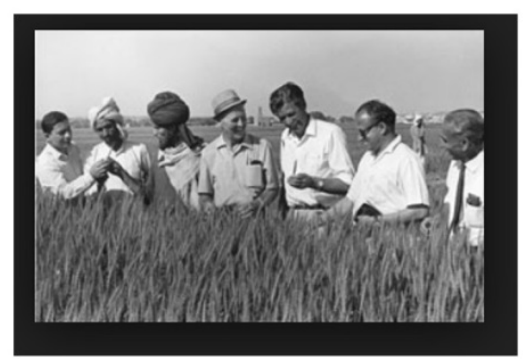

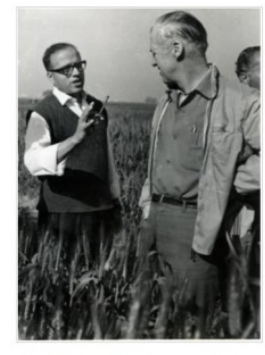

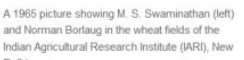

Indian Agricianta
Deli.
OMSSRF

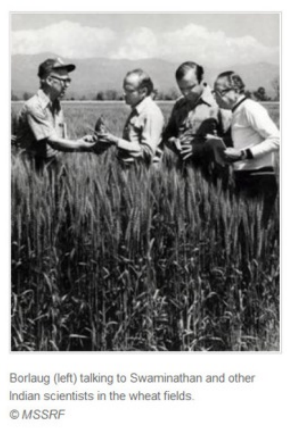

M S Swaminathan $\theta$ @msswaminathan

2+ Follow

\section{Norman Borlaug \& I travelled over wheat areas of North India in March 1964 and returned to Delhi on March 24th}

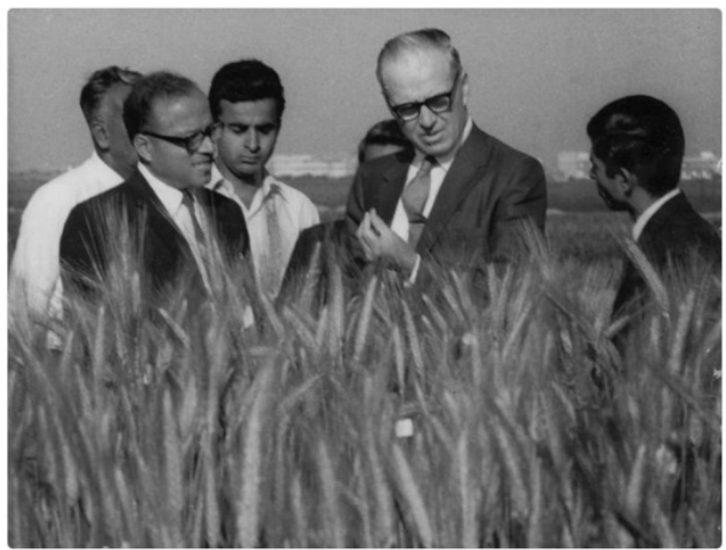

Figure 20: Decades later, MS Swaminathan was posting photos of him and Borlaug in Green Revolution wheat fields. Source: Twitter.

Individual organism. Corn shows became popular during the first decade of the 20th century in the US. They were most prominent in the Midwest, but they were held in a hierarchy that reached to the national level, at which a single ear would be crowned world champion (Kloppenburg 2004; Wallace and Brown 1956). The shows were sponsored by growers' associations, input companies, and schools of agriculture, and the prizes to winners - often including cash and farm equipment — could be enormous. Winners also earned a measure of fame as they and their prize ears were depicted in newspapers (Figure 2). ${ }^{9}$ Corn ears were scored by judges, most of whom came from institutions like agricultural experiment stations and land grant colleges. The point was to make a spectacle of corn that conformed to standards established on the judges "show cards", encouraging farmers to adopt varieties with those traits. When commercial varieties appeared in the winners' circle it led to boosts in adoption and also a boost in price (Kloppenburg 2004: 95).

Although many insisted that good-looking corn was good-performing corn (Figure 21), the appearance of a cob and its conformity to the standards on a show card was a classic example of a biased agricultural heuristic. This may seem obvious to us in hindsight, but it was voiced at the time by agronomists like Love and Wentz who ran experiments on the performance of winning ears and wrote that "the points emphasized on a score card are of no value for seed ear purposes and are entirely for show purposes" (1917:322).

\footnotetext{
${ }^{9}$ The best looking ear might even be immortalized. The Missouri Corn Growers Association held a corn show in 1926 at the University of Missouri, where a new building for the agriculture school was under construction. The winning ear, along with its scorecard, were placed in a copper tube and laid into the cornerstone of the building (Mertens 2014).
} 

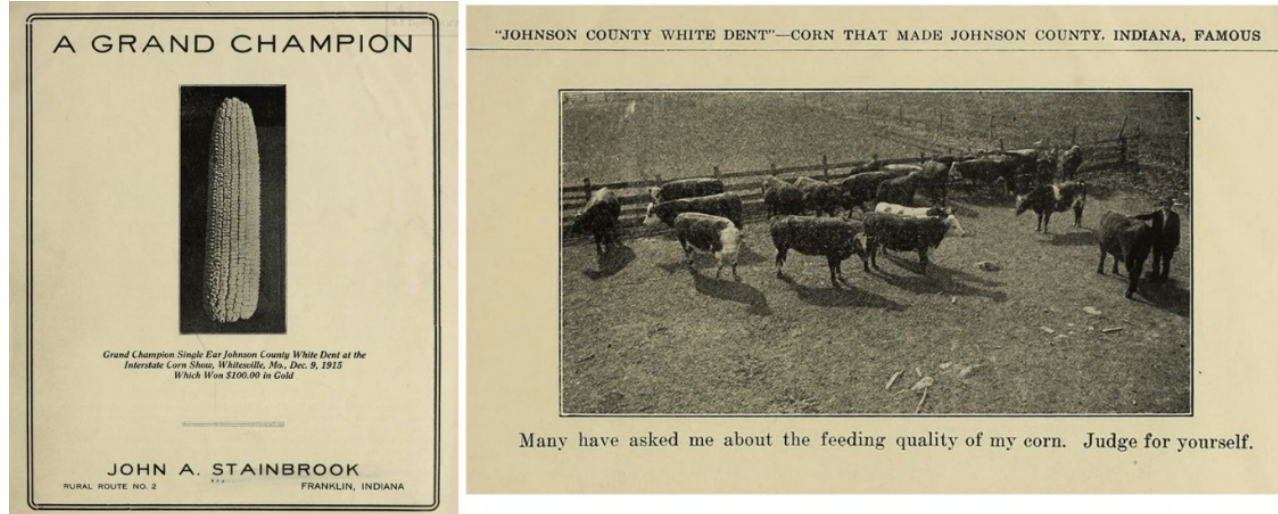

Figure 21: Front cover and one image from a 1915 pamphlet advertising a grand champion variety of corn and its feeding qualities. Source: Stainbrook (1915).

In fact, the growing of show corn actually depressed yields by encouraging genetic uniformity and reduction in vigor, and by "replacing a multiplicity of varieties with economically inferior but aesthetically pleasing show-derived strains and through their influence on the selection criteria employed by farmers" (Kloppenburg 2004: 96).

Animal shows have an even longer history. In the U.S., cattle in particular have been promoted as objects of spectacle since the early 19th century. Again, the visual appearance individual animals in the "beautiful display at the county fairs... of the many beautiful animals" (Leavitt 1933: 53) became a deceptive stand-in for agricultural productivity.

Artificial Scales. The scales discussed above are all real in that they exist in actual agricultural space. But artificial scales are also created specifically for spectacle. The Corn Show is an example: here the ears each a micro-spectacle — are formed into a large array with spectacular qualities although lacking any correspondence in the world of agricultural utility (Figure 22).

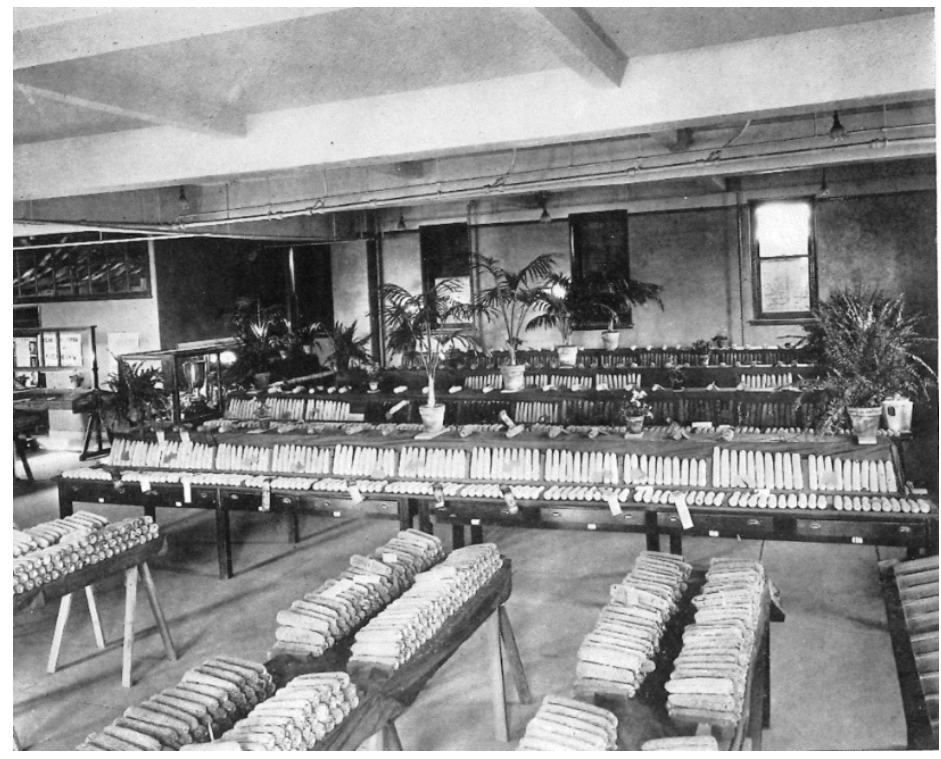

Figure 22. A corn show at the Farmers' Fair, University of Missouri 1919. Source: Savitar (1919). 
The Andhra Pradesh NGO mentioned above also provided an example of spectacle at an artificial scale. When I first arrived at the NGO field headquarters the staff insisted that we repair to a room in which the walls were almost completely paved with photos of farmers ostensibly benefiting from technologies and practices the NGO had introduced. My field notes for the day describe it as the Spectacle Room. Each individual photo depicted agriculture at a micro scale - a single or small group of farmers and a single technology such as a vermicompost bed, a tricogamma card, or a neem oil sprayer. But they had been assembled into an array covering most of the walls, suggesting that so much farmer-helping was going on for the mind to even take in (Figure 23) - an example of an artificial scale of spectacle.

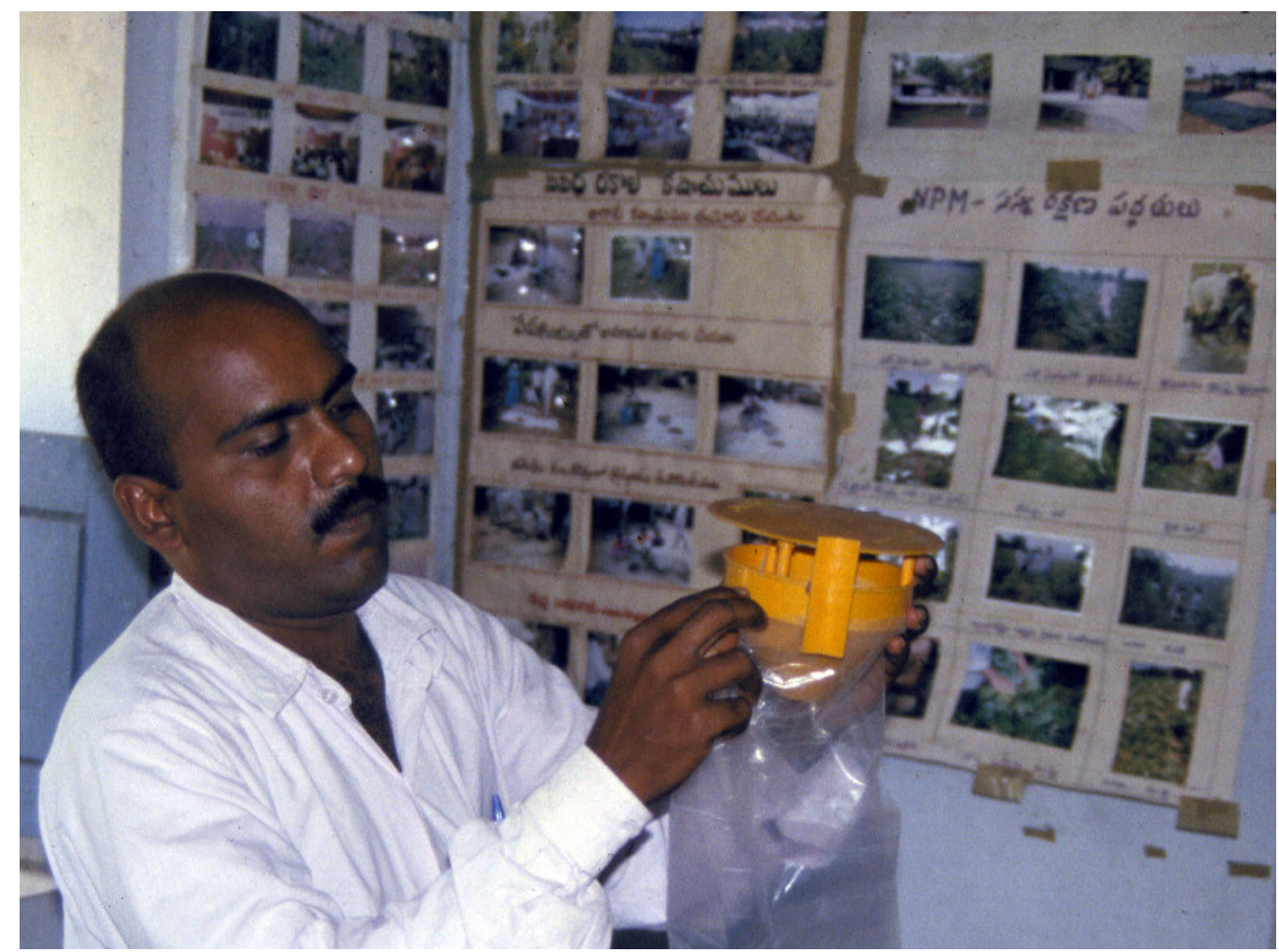

Figure 23. The "Spectacle Room" at a Warangal agricultural NGO. Three walls were covered with photographs depicting successes of agricultural interventions, few of which were still visible in the fields. (C) G. Stone.

Agricultural research centers generally have many test plots that, while operating as independent sites for experiment, collectively form an array that can operate as an artificial scale spectacle. The test plots at the International Rice Research Institute in Los Baños, Philippines, were laid out for their utility function, but they became an integral part of a Green Revolution spectacle of modernity. The Institute itself, composed of aluminum and glass structures that made no concessions to climate or local conventions, was explicitly intended as a spectacle of the power and richness of science and the American life. After IRRI opened in 1962, a thousand tourists a week came for a glimpse of the future; the tableau that awaited them was not just the Institute — which looked "like an Ohio consolidated high school perched on a volcano" (Cullather 2010: 163) — but the dazzling expanse of groomed, controlled, perfectly gridded test plots (Figure 24). 


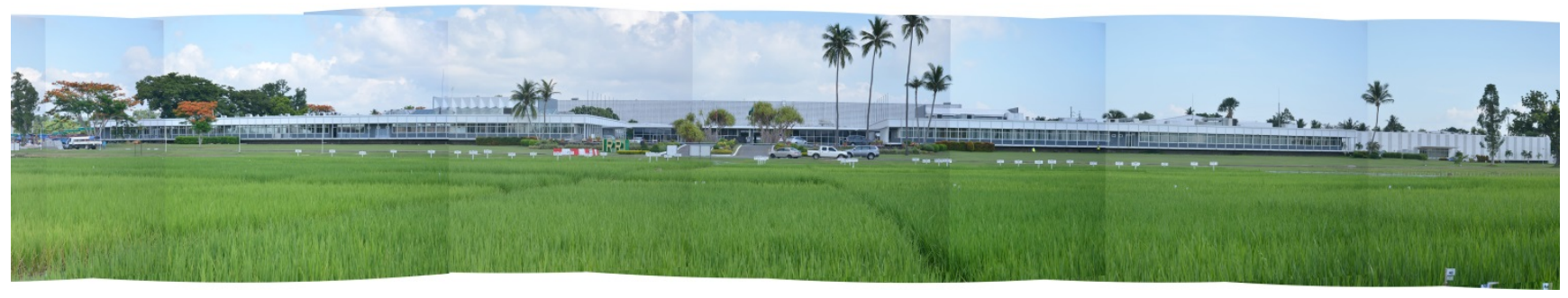

Figure 24. Expanse of test plots that form the "front yard" of the International Rice Research Institute in Los Baños. (C) G. Stone.

\section{Wrap-up}

Agriculture indeed is a performance, and Paul Richards' lens for viewing the performance has been illuminating. What we see in the field results less from a design dictated by indigenous knowledge of crops than from creative maneuvers in the social realm. The seeds may be less important than the cooking, the music and the social obligations (Richards 1989, 1993). The problem is that Richards' farmers perform to no audience, and by neglecting agriculture's diverse audiences we miss crucial elements of the performance. My focus here has been on the visual and on how the farm field that Richards sees as an unintended byproduct of performance may be fashioned to be seen, as may various other aspects of agriculture. Agriculture is presented to audiences as spectacle, the types of which are diverse. Agricultural spectacle occurs at levels ranging from landscapes to villages to plots to individual organisms. We see that agricultural sights vary in the degree to which they require narrative to become visually compelling. We see that the intent of agricultural spectacle varies, as it may be deployed to demonstrate power or sell products.

The focus on spectacle shows us how far we have come from a purely productivist reading of agriculture. Productivism generally refers to the belief in production for production's sake and to policies rewarding farmers for maximizing output (Evans et al. 2002: 314; Stone and Glover 2016: 89), but at the most basic level it is the assumption that the purpose of agriculture is agricultural produce, be it food, fiber, fodder, medicine, industrial material, or what have you. Richards reconceptualized the productive process not scripted but improvisational — and the nature of agricultural inputs — not just labor and technology, but a range of skillful social interactions - but not the output: what his performative farmers were up to was producing rice, sorghum, millet and cassava, and the takeaway was that the labor-mobilizing performance was a key to producing those goods. But we have seen that agriculture is about much more than producing plants and animals: it also produces spectacle, and spectacle may be not just a byproduct but a primary output. The spectacle itself rarely contributes to production and may even detract, but it may affect how much the farmer can sell products for, how many farmers adopt a technology, and what others think about particular forms of production or about the spectacle-makers themselves. And the spectacle may itself be a money-maker.

The focus on the presentation of agriculture to achieve an effect on an audience immediately suggests many lines of future research. For instance, I have problematized the concept of agriculture being conducted "for show", which raises questions about economics at each level. The one level at which this has been explored is the level of the corn cob: researchers of the history of agriculture have analyzed how competitions over cosmetic qualities disadvantaged overall corn improvement, even as it advantaged the small number of corn show winners (Kloppenburg 2004: 94). But consider the level of the farm: for Neo-agrarian operations in which the farm itself serves as a spectacle, how do the benefits of having a lovely farm for visitors compare to the costs of keeping it looking that way? What does it actually cost to maintain the show landscape at Hachirogata, and who actually benefits from the show?

This survey, although wide-ranging, has only scratched the surface of a topic that is rife with implications for future research. Untouched have been the intersecting questions of race, gender and ethnicity in agricultural spectacle. There are fruitful questions concerning down-home versus professionalized 
production of various types of spectacle. Important from a political-ecological perspective are questions of how power operates when spectacles are contested. Other questions concern the actual effects of agricultural spectacle. Effects are generally difficult to isolate but if spectacles are created for specific purposes it is obviously of interest if their aims are met. The rural NGO's "spectacle room" certainly furthered the image of a record of hands-on success in the eyes of many visitors, but local farmers who found their way into the room would surely have been struck by the many photos of interventions known to have been abandoned. Did some of them begin to think of the NGO schemes as scams?

Analysis of agricultural spectacle will be particularly useful given the rising importance of depictions and characterizations of agriculture in a world with a growing chasm between our interest in food and our alienation from food production. The percentage of world population engaged in farming and living in rural areas continues to shrink (even if this process is checked in some areas by repeasantization movements (van der Ploeg 2008)), meaning that the world is becoming distant and ignorant of farming. And yet even as farms become increasingly unknown, our interest in food has never been higher: witness the rapidly-growing body of food research in multiple academic fields, the ever-rising numbers of food writers, food studies courses, and food documentaries, and the surge in agritourism in its various forms (Carpio et al. 2008; Fleischer et al. 2018). ${ }^{10}$ Representations of farms to those outside of the agrarian community will only grow in importance. Creation of spectacle will always be a core element in such representation.

\section{References}

Addo, P.A. 2009. Anthropology, festival, and spectacle. Reviews in Anthropology 38: 217-236.

Ajith, C. 2017. How this Telangana village banished poverty and farmer suicides through organic farming. Huffington Post, Dec 26.

Appleton, J. 1996. The experience of landscape. London: Wiley.

Baranski, M.R. 2019. Globalizing wheat: success and failure of the Green Revolution. West Lafayette: Purdue University Press.

Batterbury, S.P.J. 1996. Planners or performers? Reflections on indigenous dryland farming in northern Burkina Faso. Agriculture and Human Values 13: 12-22.

Borlaug, N., I. Navarez, O. Aresvik and R.G. Anderson, 1969. A Green Revolution yields a golden harvest. Columbia Journal of World Business 5: 9-19.

Burton, R.J.F. 2004. Seeing through the 'good farmer's' eyes: towards developing an understanding of the social symbolic value of 'productivist' behaviour. Sociologia Ruralis 44: 195-215.

Caprotti, F. and M. Kaïka. 2008. Producing the ideal fascist landscape: nature, materiality and the cinematic representation of land reclamation in the Pontine Marshes. Social and Cultural Geography 9: 613-634.

Carpio, C.E., M.K. Wohlgenant and T. Boonsaeng. 2008. The demand for agritourism in the United States. Journal of Agricultural and Resource Economics 33: 254-269.

Chambers, R. 2006. Poverty unperceived: traps, biases and agenda. Working Paper 270. Brighton: Institute of Development Studies.

CowSignals. 2015. Cows coming out in the summer. Happy cows! CowSignals Youtube channel, https://www.youtube.com/watch?v=uA8dAnlD51o

Cullather, N. 2010. The hungry world: America's cold war battle against poverty in Asia. Cambridge MA: Harvard University Press.

Darby, M.R. and E. Karni. 1973. Free competition and the optimal amount of fraud. Journal of Law and Economics 16: 67-88.

Debord, G. 1967. The society of the spectacle. Trans. 1970, Detroit: Black \& Red.

\footnotetext{
${ }^{10}$ Note, for instance, that in China where urban migration has been particularly high, the agritourism market is developing faster than domestic tourism (Youxue et al. 2016).
} 
Debord, G. 1988. Comments on The Society of the Spectacle. Trans. 1998, London: Verso.

Dutton, D. 2009. The art instinct: beauty, pleasure, and human evolution. New York: Bloomsbury.

Edwards, D.M. 1999. Show windows of the West: exhibitionary complexes and the promotion of Montana's agricultural possibilities. Agricultural History 73: 322-348.

Evans, N., C. Morris and M. Winter. 2002. Conceptualizing agriculture: a critique of post-productivism as the new orthodoxy. Progress in Human Geography 26: 313-332.

Flachs, A. 2017. "Show Farmers": transformation and performance in Telangana, India. Culture, Agriculture, Food and Environment 39: 25-34.

Fleischer, A., A. Tchetchik, Z. Bar-Nahum and E.Talev. 2018. Is agriculture important to agritourism? The agritourism attraction market in Israel. European Review of Agricultural Economics 45: 273-296.

Freidberg, S. 2009. Fresh: a perishable history. Cambridge: Belknap Press of Harvard University Press.

Glover, D. 2007. The role of the private sector in modern biotechnology and rural development: the case of the Monsanto Smallholder Programme. PhD thesis in Development Studies. Brighton: University of Sussex.

Goethe, J.W. 1840 [1810]. Theory of colors. London: John Murray.

Gotham, K.F. 2007. Critical theory and Katrina. City: Analysis of Urban Trends, Culture, Theory, Policy, Action 11: 81-99.

Holloway, L. 2004. Showing and telling farming: agricultural shows and re-imaging British agriculture. Journal of Rural Studies 20: 319-330.

Holloway, L. 2005. Re-imaging agriculture: making the case for farming at the agricultural show. In Essex S. (ed.). Rural change and sustainability: agriculture, the environment and communities. Wallingford: CABI. Pp. 122-134.

Huntley, H.E. 1970. The divine proportion: a study in mathematical beauty. New York: Dover.

Igoe, J. 2013. Nature on the move II: contemplation becomes speculation. New Proposals: Journal of Marxism and Interdisciplinary Inquiry 6: 37-49.

Igoe, J. 2017. Nature spectacle: on images, money, and conserving capitalism. Tucson: University of Arizona Press.

Jacobelli, L. 2003. Gladiators at Pompeii. Los Angeles: Getty Publications.

Jordahn, S. 2017. World Landscape of the Year 2017 teaches people about China's farming history. Dezeen.

Kahneman, D. 2011. Thinking, fast and slow. New York: Farrar, Straus and Giroux.

Kloppenburg, J.R., Jr. 2004. First the seed: the political economy of plant biotechnology, 1492-2000. 2nd edition. Madison: University of Wisconsin Press.

Leavitt, C.T. 1933. Attempts to improve cattle breeds in the United States, 1790-1860. Agricultural History 7: 51-67.

Lefebvre, H. 1991[1974]. The production of space. Oxford: Blackwell.

Linne, T. and H. Pedersen. 2017. With care for cows and a love for milk: affect and performance in swedish dairy industry marketing strategies. In A. Potts (ed.) Meat Culture. Leiden: Brill. Pp. 109-128.

Love, H.H. and J.B. Wentz. 1917. Correlations betveen ear characters and yield in corn. Journal of the American Society of Agronomy 9: 315-322.

Maat, H. 2011. The history and future of agricultural experiments. NJAS - Wageningen Journal of Life Sciences 57: 187-195.

Maat, H. and D. Glover. 2012. Alternative configurations of agronomic experimentation. In Sumberg, J. and J. Thompson (eds.). Contested agronomy: agricultural research in a changing world. London: Routledge. Pp. 131-145.

Manning, F.E. 1992. Spectacle. In R. Bauman (ed.). Folklore, cultural performances, and popular entertainments: a communications-centered handbook. Oxford: Oxford University Press. Pp. 291-299.

Misra, S.S. 2009. Made it. Down to Earth. 
Moore, R.H. 1993. Resistance to Japanese rice policy: a case-study of the Hachirōgata model farm project. Political Geography 12: 278-296.

NPR. 2001. Corn Cam, Nat Public Radio website, Aug 2.

PBS Newshour. 2012. Business fund puts African farmers on road to market. PBS.

Pollan, M. 2006. The omnivore's dilemma: a natural history of four meals. New York: Penguin.

Richards, P. 1989. Agriculture as a performance. In R. Chambers, A. Pacey and L.A. Thrupp (eds.). Farmer first: farmer innovation and agricultural research. London: Intermediate Technology Publications. Pp. 39-42.

Richards, P. 1993. Cultivation: knowledge or performance? In M. Hobart (ed.). An anthropological critique of development: the growth of ignorance. London: Routledge. Pp. 61-78.

Savitar. 1919. University of Missouri yearbook.

Slater, C. 2002. Entangled Edens: visions of the Amazon. Berkeley and Los Angeles: University of California Press.

Stainbrook, J.A. 1915. A grand champion. Franklin, Ind: John A. Stainbrook.

Stone, G.D. 2007. Agricultural deskilling and the spread of Genetically Modified Cotton in Warangal. Current Anthropology 48: 67-103.

Stone, G.D. 2014. Theme Park farming in Japan. Entry, G.D. Stone (ed.) https://fieldquestions.com/2014/06/05/theme-park-farming-in-japan/.

Stone, G.D. and D. Glover. 2016. Disembedding grain: Golden Rice, the Green Revolution, and Heirloom Seeds in the Philippines. Agriculture and Human Values 33: 87-102.

Stone, G.D., R.M. Netting and M.P. Stone. 1990. Seasonality, labor scheduling and agricultural intensification in the Nigerian savanna. American Anthropologist 92: 7-24.

Subramanian, K. 2015. Revisiting the Green Revolution: Irrigation and food production in 20th Century India. PhD thesis. London: King's College London.

Tomlinson, A. 2002. Theorising spectacle: beyond Debord. In J. Sugden and A. Tomlinson (eds.) Power games: a critical sociology of sport. London: Routledge. Pp. 44-60.

Troyer, A.F. and L.S. Palmer. 2006. Background and importance of Troyer Reid corn. Crop Science 46: 2460-2467.

Tsing, A.L. 2005. Friction: an ethnography of global connection. Princeton NJ: Princeton University Press.

Tversky, A. and D. Kahneman. 1974. Judgment under uncertainty: heuristics and biases. Science 185: 11241131.

van der Ploeg, J.D. 2008. The new peasantries: struggles for autonomy and sustainability in an era of empire and globalization. London: Earthscan.

Wallace, H.A. and W.L. Brown. 1956. Corn and its early fathers. Lansing: Michigan State University Press.

Watts, M.J. 1983. Silent violence: food, famine, and peasantry in northern Nigeria. Berkeley: University of California Press.

Wood, D.C. 2012. Ogata-Mura: sowing dissent and reclaiming identity in a Japanese farming village. New York: Berghahn.

Youxue, J., W. Shujin and C.-C. Tsai. 2016. Study on the consumption of agritourism in China. 2016 Joint International Conference on Service Science, Management and Engineering (SSME 2016) and International Conference on Information Science and Technology (IST 2016). 